\title{
Tensions and Opportunities: An Activity Theory Perspective on Date and Storage Label Design through a Literature Review and Co-Creation Sessions
}

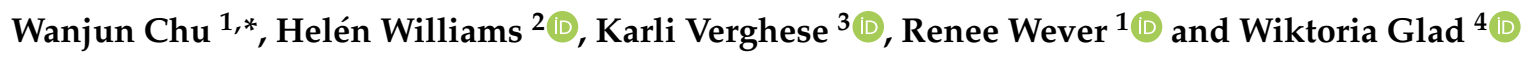 \\ 1 Department of Management and Engineering, Linköping University, SE-581 83 Linköping, Sweden; \\ renee.wever@liu.se \\ 2 Service Research Center and Department of Engineering and Chemical Sciences, Karlstad University, \\ SE-651 88 Karlstad, Sweden; helen.williams@kau.se \\ 3 School of Design, RMIT University, 3001 Melbourne, Australia; karli.verghese@rmit.edu.au \\ 4 Department of Thematic Studies, Linköping University, SE-581 83 Linköping, Sweden; wiktoria.glad@liu.se \\ * Correspondence: chu.wanjun@liu.se
}

Received: 15 November 2019; Accepted: 30 January 2020; Published: 6 February 2020

\begin{abstract}
On-pack date and storage labeling is one of the direct information carriers used by the food industry to communicate product shelf-life attributes to consumers. However, it is also one of the major factors that contribute to consumer food waste issues. This study aims to systematically understand the existing tensions within the current date and storage labeling system and explore the potential opportunities for design to intervene. First, we conducted a literature review to identify tensions that the consumer encounters in their food edibility assessment system and summarize the corresponding proposal for actions. 12 tensions and 16 proposals for action were identified and further framed according to a conceptual model developed in this study. Following this, the literature findings were refined and grounded in co-creation sessions in consumer workshops and industry practitioner interviews to develop specific labeling-related design implications. The findings indicate the importance of investigating the role that date and storage labeling play from a system level. Furthermore, we suggest that the conceptual model developed in this study can be used not only as a framework that guides researchers to identify and analyze labeling-related food waste problems that each individual consumer encounters, but also as a guideline that assists packaging design practitioners in exploring potential design opportunities to solve the problem from a system perspective.
\end{abstract}

Keywords: packaging design; date labels; food waste; design for sustainable behavior; activity theory

\section{Introduction}

Over the past decade, the problem of consumer food waste caused by packaging has gained much attention globally (e.g., [1-3]). However, the relationship between food waste and packaging is still marginally understood [4,5]. According to Wikström et al. [6], the environmental impact of packaging concerning food waste can be divided into two categories: direct impacts, which include the optimization of packaging attributes such as volumes, materials and mechanisms; and indirect impacts, which are dependent on consumer behavior. While most of the existing studies focus on measuring and reducing the direct environmental impact of packaging, the question of how these packaging attributes might influence consumer household food consumption and waste behavior has rarely been explored [6,7].

Among the indirect impacts of packaging, date and storage information attributes play a significant role in a consumer's decision of whether to eat or discard food [8]. From a socio-historical perspective, 
date and storage labeling has evolved from a business-oriented tool for internal stock control to a consumer-oriented tool for better food management in households [9]. Nowadays, on-pack date and storage labeling is widely used as an indicator to inform consumers about quality ("Best before" date) and the safety ("Use by" date) status of food. According to Food Information to Consumers (FIC) legislation implemented in the EU (Regulation No 1169/2011) [10], "Best before" labeling relates primary to food quality, and food that passed the date may still keep an acceptable quality if stored properly. "Use by" date relates primary to food safety, and food that passed the date may be likely to pose an immediate danger to human health and thus should be deemed as unsafe to eat [10].

This "Best before" and "Use by" date labeling communication system, to a large extent, is based on the prerequisite that the individual consumer can correctly interpret the delivered label information and make rational decisions [11]. In consumer food consumption practices, the way consumers assess the edibility of food products can be highly influenced by various factors such as the interpretation of label meaning, the use of sensory perceptions, the dilemma of food waste or safety, past experiences and existing habits [8,11-15]. In addition, the terminology, format and location of the date and storage guidance vary on packaging, as does consumer understanding, interpretation and usage of these on-pack information attributes [12,14,16-19]. The results from a comprehensive survey conducted in the EU indicated that only less than $50 \%$ of Europeans understand the meaning of the "Best before" date, and less than $40 \%$ understand the meaning of the "Use by" date [11,13].

Consequently, date and storage labeling has become one of the major factors that dominate packaging-related household food waste [12,20-25]. In the UK, at least 450,000 metric tons of food is thrown away every year because the food has passed its "Best-before" date, and an additional of 380,000 metric tons of food is thrown away as the food has passed its "Use-by" date [12]. In the US, the total consumer economic loss due to confusion over the meaning of date labels is estimated to be approximately 29 billion dollars each year [26]. Moreover, labeling-related food waste is not only a challenge that the current generation faces; the issue is likely to shift over generations if the status quo remains unchanged. According to a survey conducted in the US in 2001, fewer people at the time were able to correctly identify the meaning of the date labels on milk products than in the 1980s [27]. A recent national survey in the US also pointed out that millennials tend to solely regard date labels as food safety indicators and discard food that has passed the date [28]. As a result, perfectly edible food products that have "Best before" dates or without any date labels are more likely to be wasted due to such misconception. The findings from the above studies all suggest that measures need to be taken to ensure that labeling-related food waste does not continue to grow with future generations [28].

However, on-pack date labeling seems to be both a major factor that triggers the consumer household food waste as well as an avenue for reducing it [12]. Improvements on the current labeling communication system have been identified as the most cost-effective measure to reduce consumer food waste. Specifically, improvements on date labeling would not only bring the greatest economic value per ton in terms of food waste reduction on the consumer side but would also require the lowest cost on the business practice side [26]. In other words, minor innovations in date and storage labeling can enable profound changes in consumer food waste behavior. Therefore, despite the original intention of helping the consumer make a more informed choice in their food consumption, nowadays, date and storage labeling has also been assigned the role of remedying household food waste [9].

Approaching this emerging packaging-related problem from a design perspective, various design suggestions have been proposed in recent years, which specifically targeted improving consumers' interaction with on-pack date and storage labels [7]. According to Lyndhurst [12], these suggestions can be generally categorized into two perspectives. From the perspective of on-pack label information design, a variety of practical tools, such as detailed labeling design guidelines for "Best before" and "Use by" date [29,30] and a decision tree for date marking [31], have been developed for industry practitioners to ensure that their labeling communication is accessible and meaningful to consumers. From the consumer perspective, behavior change interventions, such as information campaigns [32], 
mobile applications [33] and smart label indicators [34] have been developed to optimize consumers' correct understanding and usage of labels.

However, as consumer interactions with on-pack labels are highly influenced by various factors, focusing solely on one perspective (either label presentation or consumer behavior) is likely to be insufficient when it comes to effectively reducing labeling-related food waste [35]. A holistic lens that investigates the usage of date labels in consumers' broader food edibility assessment system is needed for design researchers to better understand the problem. Moreover, the translation of theoretical knowledge from date labeling and food waste literature to practical design implications is missing in existing studies.

As a first step to fill this knowledge gap, in the present study we aim to explore the potential opportunities for design to intervene in the interaction between consumer and date labeling to reduce household food waste. First, we focused on understanding the tensions that the consumer encounters in relation to labeling and summarizing the existing proposals for action to ease the tensions. This part was done by conducting a systematic literature review. By examining the literature review results through an activity theoretical lens, we developed a conceptual model to systematically frame the identified tensions and proposals for action. Following that, to better translate the literature insights into more practical design implications, we conducted consumer workshops and industry practitioner interviews in order to ground the review findings. By incorporating the insights from workshops and interviews with the literature review, we identified potential design opportunities to help consumers in preventing labeling-related food waste.

\section{Activity Theoretical Lens}

Activity theory (AT) was chosen as the theoretical framework in the present study. Activity is interpreted as subjects' interaction with specific artifacts to achieve specific objects within specific real-life circumstances [36]. In this study, we took people's food edibility judgment activity as the unit of analysis. According to AT, human activity is mediated by the use of tools [37]. The tools can be external, such as a hammer, a phone, and a computer, which are intended to be used to manipulate physical objects. The tools can also be internal and abstract, such as the multiplication table, a cognitive model, and language [38]. Within the consumer food waste topic, similar concepts of external and internal tools have also been proposed and applied by Hebrok and Heiddenstrom [14] and Ygnfalk [39]. In their studies, the knowledge that people need for assessing the edibility of food items through date labels is defined as external institutionalized knowledge, while the knowledge needed for assessing the edibility of food items through sensory perceptions is defined as embodied knowledge. In the present paper, we integrate their definitions with the theoretical concept of AT, and view the on-pack date and storage labels as the external mediating tools and consumers' knowledge and sensory perceptions as the internal mediating tools.

AT has been adopted in various design research studies as the analytical framework for developing understandings of sustainability problems from a systematic perspective (e.g., [40-43]). We have previously applied the AT theoretical lens to analyze people's food consumption activities in an explorative case study [44]. Results from the case study showed that AT has two main strengths in terms of studying consumer food consumption activities. First, AT particularly focuses on understanding the role that different mediating tools play in people's activity systems. This emphasis can provide us with a unique perspective from which to view food packaging not only as a shelf life and storage information carrier, but also as a mediating tool that consumers interact with in their daily food consumption activities. Furthermore, individual consumers' packaging-related food waste behavior can be shaped by not only the on-pack labels and their own knowledge, but also by industry practices and government regulations. AT can help frame the empirical data from multiple perspectives into an integrated model (as presented in Figure 1). 
Macro activity layer

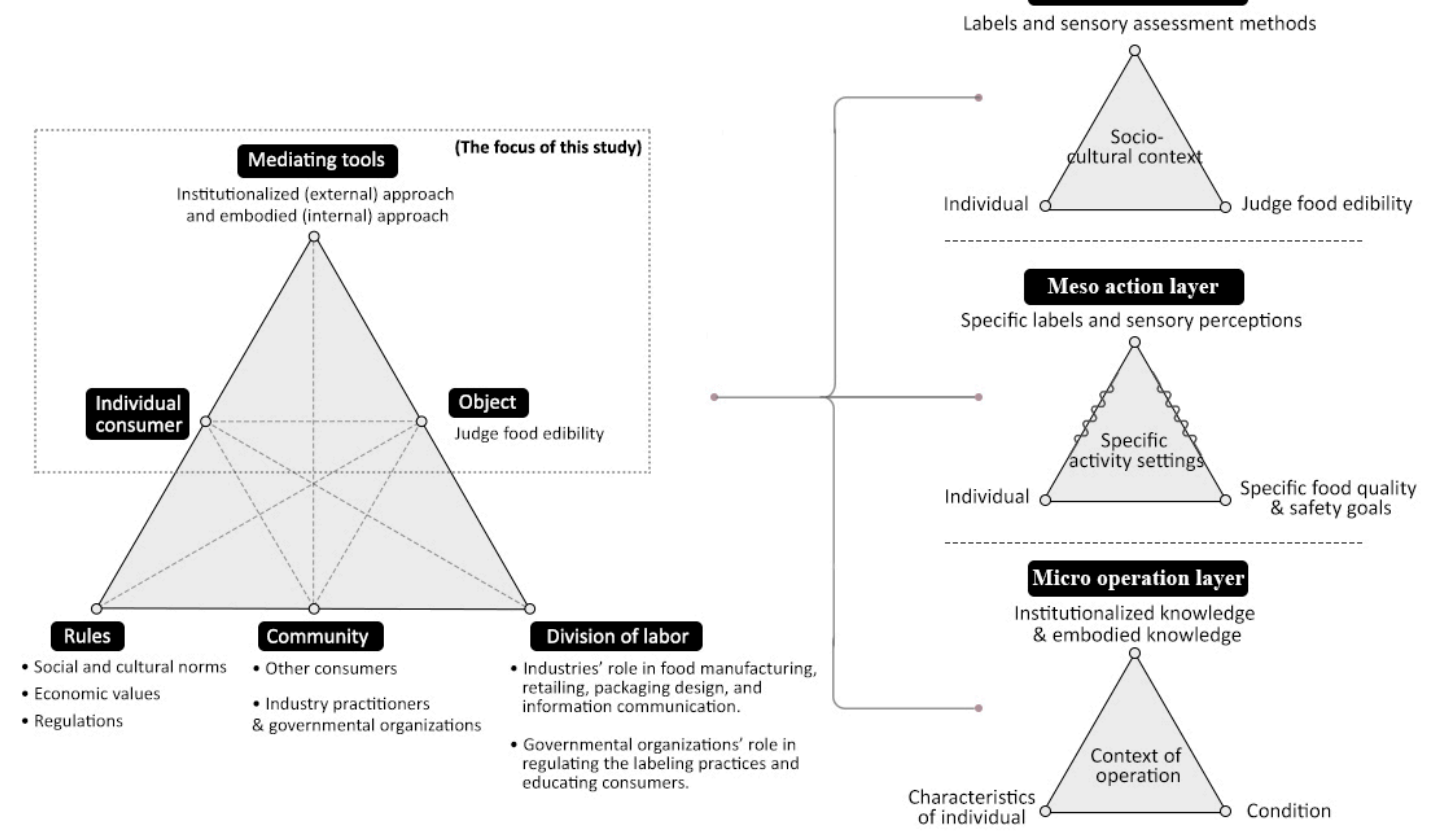

Figure 1. Activity theory (AT) analytical model used in this study (adapted from [45]).

\section{Materials and Methods}

In order to develop an in-depth understanding of the tensions that the consumer encounters when interacting with labeling and explore potential design opportunities, we drew upon insights from three perspectives: existing literature, general consumers, and industry practitioners. A similar research setup has been applied in previous studies within the packaging-related food waste topic (e.g., [5,15]). We followed the methodological approach applied in Verghese et al. [46], in which personal insights from different stakeholder interviews were combined with a literature review so as to reach a more profound analysis of packaging opportunities. We acknowledged that the limitation of this approach is the extensive efforts that the data gathering and analysis process may take. Therefore, to better structure the study, we divided the study into three phases (see Figure 2).

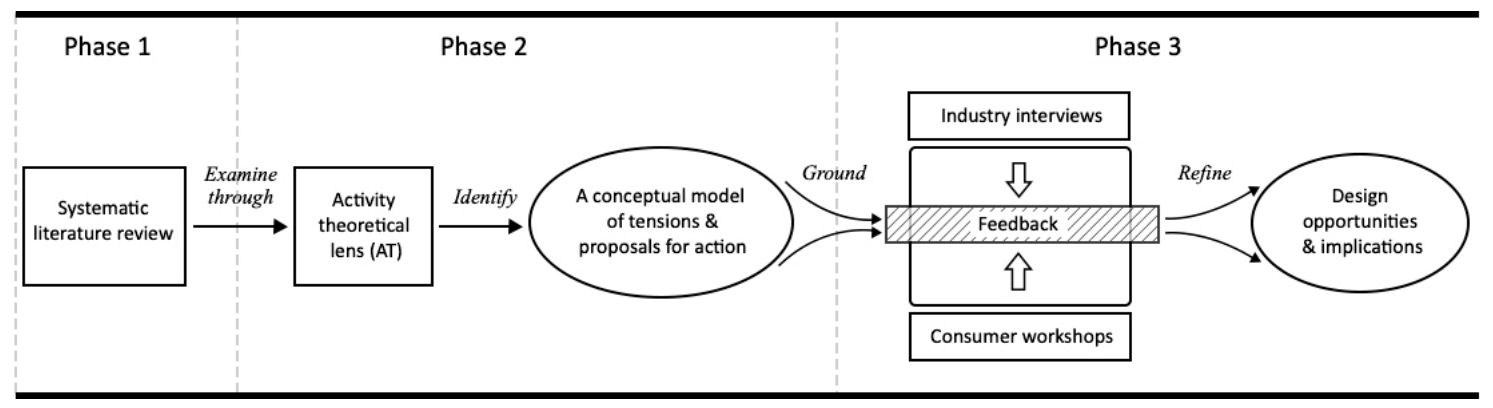

Figure 2. An overview of the research approach.

First, we conducted a literature review to extract tensions and existing proposals for action in relation to labeling (as presented in Section 3.1). Then, we examined the literature review results through an AT theoretical lens. Following this, we grounded the literature findings in consumer workshops and industry interviews with 10 consumers and 10 industry participants (as presented in Section 3.2). Although the participant sample number is small, we argue that it was necessary to have such a "reality-check" to see if the literature insights were applicable or needed to be adapted to real contexts. Furthermore, the proposals for action we extracted from the literature review were rather 
abstract and theoretical. Therefore, we employed the consumer workshop and industry interview as a way to translate these general literature insights into more concrete labeling-related design implications. In this paper, we refer to the consumer workshop and industry interview as co-creation sessions following the definition given by Sanders and Stappers [47], which means that designers and people not trained in design work together in the design development process to solve a problem. Furthermore, from a Research through Design perspective [48], this step is an efficient way to gain multiple perspectives on the identified research problem and develop an early grounding of the problem in design [49].

\subsection{Literature Review}

The goal of the literature review is to compile existing knowledge regarding how date and storage labels are used by consumers in their food assessment activities. We adopted the systematic literature review guideline developed by Kitchenham and Charters [50]. This guideline was selected due to its extensive application in the design and engineering fields, which matches the general design perspective of the study. Furthermore, the guideline was derived from existing systematic literature review methods used in medical and social science disciplines and it covers a wide variety of evidence-based practices [50,51]. Note that the major part of the review was conducted by a single researcher. Therefore, in this case, we followed the 8 key literature review steps for a single researcher as suggested in Kitchenham [52]: 1) develop a review protocol, 2) define the literature review goals and research questions, 3) specify problems and actions of a single researcher applying inclusion/exclusion criteria and undertaking all the data extraction, 4) define the search strategy, 5) define the data to be extracted from each primary study, 6) maintain lists of included and excluded studies, 7) use the data synthesis guidelines and 8) use the reporting guidelines. An overview of the literature review procedures is presented in Figure 3.

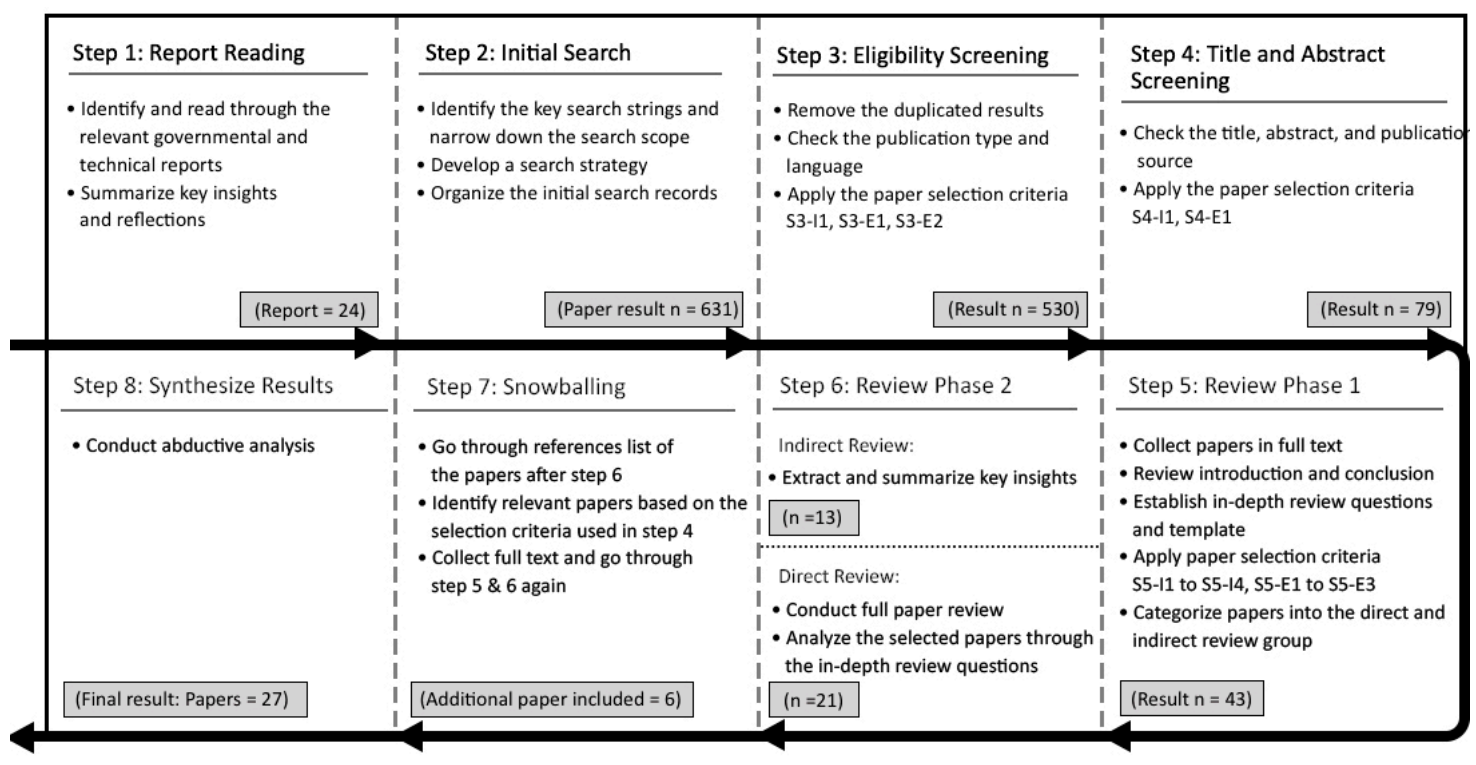

Figure 3. Literature review procedures used in this study.

\subsubsection{Identification of Research}

In order to determine a search strategy that fits the context of this study, we began the preliminary searches by identifying packaging and consumer food waste-related technical reports (presented as step 1 in Figure 3). Given the fact that the consumer food waste research topic has been widely studied in the context of developed countries and regions [53], we searched through relevant technical reports published by governmental, non-governmental, and research organizations in the EU, UK, US and AU. These organizations include WRAP, DEFRA, FSA, Love Food Hate Waste, Nordic Co-operation, 
European Commission, NRDC, ReFED and Australian Institute of Packaging. The authors of this paper identified the above organizations and technical reports based on their professional knowledge in the packaging and food waste field. We also used snowball sampling to include additional relevant reports. In total, we identified 24 technical reports related to on-pack date and storage labeling. Note that these reports did not go through an in-depth review due to their excessive length and coverage of a wide range of topics. They were thus included as supporting literature, and only key findings related to labeling were extracted from these reports.

One of the reflections we developed from the above reports is that date and storage labeling have been discussed in a variety of studies with different focuses such as food shelf life, packaging design, food waste and food safety. Based on this insight, a combination of two groups of search terms was derived. As presented in Table 1, search group 1 consisted of independent search terms that were directly related to date and storage labeling. Search group 2, which consisted of a combination of search terms covering topics such as shelf life and consumer behavior, was used to provide a complementary view and ensure that the relevant literature published in other research areas was also included in the review. In order to minimize the potential publication bias, conference papers, journal articles and book chapters published between 1960 to March 2019 were included in the literature search. Acknowledging that the date labeling studies were widely distributed across different themes and disciplines, Scopus was chosen as the search platform as it claims to be the largest database of abstracts and citations and covers an extensive number of peer-reviewed conference papers and journal articles that spread across different disciplines. The search results were documented and updated in sufficient detail for readers to assess the thoroughness of the search. As presented in Figure 3, the initial search in step 2 resulted in 631 records. After assessing the records against the eligibility assessment criteria in step 3, 530 papers were included for step 4. In step 4, after the title and abstract screening, 451 papers were removed while 79 papers remained for the review stage.

Table 1. Eligibility criteria, search string and the corresponding search records.

\begin{tabular}{|c|c|c|}
\hline Search Criteria & $\begin{array}{l}\text { Search Terms and Criteria } \\
\text { Applied to TITLE-ABS-KEY }\end{array}$ & Number of Records \\
\hline Search terms used in step 2 & $\begin{array}{l}\text { Group 1: ('date labels' OR 'date } \\
\text { labeling' OR 'shelf life label' OR } \\
\text { 'food date' OR 'on-pack } \\
\text { information' OR 'on-pack } \\
\text { communication' OR 'storage } \\
\text { guidance') } \\
\text { Group 2: ('food labeling' OR 'shelf } \\
\text { life' OR 'storage information') } \\
\text { AND ('food waste' OR 'packaging } \\
\text { design' OR 'consumer behavior') }\end{array}$ & 356 \\
\hline Time span of the publication & \multicolumn{2}{|c|}{ Literature published from 1960 to March 2019} \\
\hline Eligibility criteria used in step 3 & \multicolumn{2}{|c|}{$\begin{array}{l}\text { Step 3, inclusion (referred as S3-I1): Conference papers, journal articles } \\
\text { and book chapters } \\
\text { Step 3, exclusion (referred as S3-E1): Books, notes, letters, short surveys } \\
\text { and editorials S3-E2: Papers that were not published in English }\end{array}$} \\
\hline Screening criteria used in step 4 & \multicolumn{2}{|c|}{$\begin{array}{l}\text { S4-I1: Papers that are related to the general theme of food labeling, } \\
\text { consumer food assessment, food waste and food packaging design } \\
\text { S4-E1: Papers that are irrelevant to the topic, such as studies in food } \\
\text { bio-chemistry, food nutrients, animal science, medical science and } \\
\text { medicine packaging design }\end{array}$} \\
\hline
\end{tabular}

\subsubsection{Study Selection}

In the review stage, we conducted two review rounds to select and review the articles. Specifically, review round 1 (see step 5) focused on reviewing the introduction and conclusion section of each paper. 
Following that, in the review round 2 (see step 6), we divided the papers into two groups depending on the paper's relevance to the research topic. Group 1 was comprised of papers that were directly related to the research topic, and group 2 was comprised of papers that were indirectly related to the topic. Detailed selection criteria were developed by the corresponding author through applying a test-retest approach as suggested by Kitchenham and Charters [50], which means samples of the primary studies were re-evaluated to check the reliability of the inclusion and exclusion criteria. Correspondingly, the selection criteria were also iterated and refined after each evaluation. As a result, a paper was categorized into group 1 if it met any of the inclusion criteria listed below:

- S5-I1: The paper focuses on studying date and storage labeling within the scope of consumers' food assessment, consumer food safety and waste, governmental legislation, packaging design and technology, food retailer and manufacturer practices.

- S5-I2: The paper may not specifically focus on date and storage labeling, but it provides relevant empirical evidence and further discussion of the role that labeling plays in the topics mentioned above.

- S5-I3: The paper may not center on date and storage labeling, but insights and author(s)' reflections regarding the role that labeling plays can be found in the paper.

- S5-I4: The paper may not specifically focus on date and storage labeling, but discussion regarding the relation between labeling and consumer behavior can be found in the paper. For example, consumer perception of different date labels and how this perception may influence their food assessment.

A paper was either categorized into group 2 or excluded in step 5 and step 6 if it met any of the criteria listed below:

- S5-E1: The paper only mentions date and storage labeling without further discussion. For example, the term "date label" may be mentioned in the background, results and discussion sections with no follow-up articulation of relevant arguments.

- S5-E2: The paper solely focuses on the technological development or optimization of shelf life and packaging functions that are irrelevant to labeling. This could be a mathematical model to determine food shelf life or a data analysis technique for food quality monitoring.

- S5-E3: The paper explicitly and exclusively focuses on consumer purchase behavior instead of consumer-labeling interaction in household contexts. For example, consumers' willingnessto-pay for food that is close to or beyond its expiration dates.

In step 6, we conducted full-text reviews for the papers in group 1. We also included the papers in group 2 as the supporting literature; however, only the key insights that were associated with the research topic were summarized from these papers. After the two review rounds, we went through the reference list of each selected paper and relevant papers were identified through snowball sampling by adopting the same screening criteria used in step 4.

As a result, 36 papers were excluded in step 5. For the remaining 43 papers, 9 of them were excluded in step 6. The 34 remaining papers were further divided into two groups. In group 1 , 21 papers were identified as directly related to the research topics and thus went through in-depth reviews. In group 2, 13 papers were only included as the supporting literature. Through snowball sampling conducted in step 7, another 6 papers were identified as directly related to the research topic. As a result, a total number of 27 papers was included in the final full-paper review (for detailed results see Table A1 in Appendix A). All the papers are peer-reviewed journals papers except Yngfalk [39], which is a book chapter.

\subsubsection{Data Extraction and Data Synthesis Procedures}

To better extract data from the selected papers and avoid the risk of selective reporting, we developed a set of in-depth review questions and used it as a template for data extraction. 
These questions covered information such as research question, study focus, research method and key results. In the process of reviewing literature in each step, we also found that other study characteristics such as research perspective, food product category and the socio-cultural background of the study are of crucial importance when comparing literature results. Reflecting on this, we iterated the template based on what we have learned from reading the papers in each review step. In addition, as suggested by Kitchenham and Charters [50], a text-retest process was performed by the corresponding author to check data extraction consistency, which means that all of the selected papers in step 6 have gone through two rounds of data extraction to minimize risk of bias. The in-depth review questions for data extraction were:

- What is the main research question that the study aims to address and what is the specific research perspective that the study uses to approach the proposed research question? (e.g., food safety, household food waste, consumer food perception, industry practices, legislation);

- What is the overarching research methodology of the paper?

- What is the geographical region of the study (e.g., the UK, US, EU, AU)? And what food product category is taken as the focus of the study (such as fruits and vegetables, meat, dairy products, ready-to-eat products, refrigerated products)?

- What are the key findings of the role that date and storage labeling plays in consumer food edibility judgment?

- What suggestions or proposals for action regarding date and storage labeling are proposed in the study?

The extracted data were synthesized in an abductive approach. The data synthesis in this study was descriptive rather than quantitative. We conducted three rounds of data synthesis. First, we extracted the raw data from the selected papers in a spreadsheet according to the in-depth review questions listed above. Then, the extracted raw data were summarized in a table for better data presentation and comparison (see Table A1 in Appendix A). Second, we focused on identifying recurring themes across the papers. Themes with similar patterns and also contradictory results were grouped and analyzed. These themes include "confusion over the meaning of labels", "consistency on label content and display", "label information presentation", "sensory assessment", "food handling knowledge", "use by date usage", "best before date usage", "label on opened products", "technological innovation", "smart labels", "opened products", "consumer education", "contextual settings", "tailored communication" and "household food management". However, the results from the second round of analysis still seemed scattered rather than systematic. In the final round of analysis, AT was adopted as an analytical tool to systematically compile all the above themes. An extensive summary of using AT to guide analysis and design explorations can be found in Clemmensen et al. [54]. To be more specific, we constructed the consumer food edibility assessment activity system by following the theoretical concepts of motivation, goals, meditating tools, outcomes and tensions between different constituents within the activity system. The previously identified themes were categorized and synthesized in relation to the theoretical concepts mentioned above. As illustrated in Figure 4, the data synthesis process is iterative: we repeated the procedures several times in order to make the literature review results accurate and comprehensive.

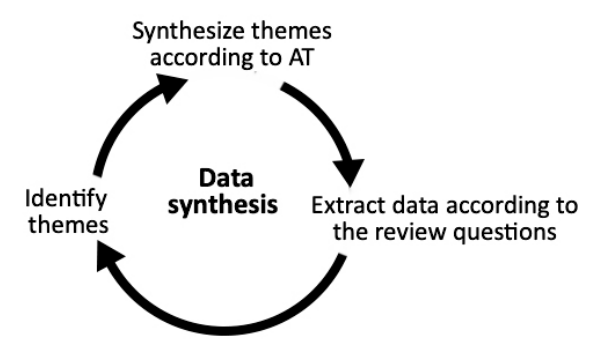

Figure 4. Literature data synthesis process. 


\subsection{Consumer Workshops and Industry Practitioner Interviews}

The goal of the consumer workshop and industry interview was to develop understandings of whether the proposals for action identified from the literature are applicable or need any adjustments in the context of both consumer and industry practices. To narrow the scope of discussion, we set the boundaries of food categories to: (1) fruits and vegetables, (2) pre-packed meat products, (3) bread and (4) dairy products (e.g., cheese, butter, yogurt and milk). These four categories were chosen as date and storage labeling problems on these food products were identified as one of the major factors that contribute to consumer household food waste [12,17]. To stimulate discussions, one representative product sample from each product category found in local supermarkets was brought to the workshop and interview settings. All the consumer workshops and industry interviews were audio recorded and fully transcribed. Various forms of data such as interview transcriptions, observation notes and participant sketches were gathered for analysis. Findings from the literature review were used as a guideline to collect participants' personal insights regarding the labeling issues. The collected data were analyzed in a deductive approach by following the themes that we identified from the literature review.

\subsubsection{Consumer Workshops}

The focus of the consumer workshop was to encourage participants to come up with design ideas to address the tensions we identified from the literature. The consumer workshop was conducted at a university in Sweden. 10 participants were recruited through the authors' professional networks. They were selected based on their interest to participate in the study. Two workshop sessions were organized, each with 5-6 participants.

Each consumer workshop lasted for 75-90 min and was comprised of three stages (see Figure 5). In the first stage, all participants were given a 10-min brief introduction to the overall on-pack date and storage issues. Following this, we carried out a 20-30-min focus group discussion to enable participants to reflect on their own behaviors in their everyday life contexts and to share their opinions with other participants. A sample of questions we developed from literature findings for discussion included: Do you use date labels and storage guidance in conjunction with your knowledge and sensory perceptions to tell whether the food is okay to eat or not? In what contexts do you rely on food labels? And in what contexts do you rely on your own judgment? If you are looking for date label and sensory knowledge, which channels would you use? Would you use date information, such as "Use within X days after first opening" on packaging? How do you think about technological innovations on labeling such as smart labels? In the third stage, we encouraged participants to think aloud and come up with design ideas to tackle the problems that they had identified in the previous sessions. Participants were further divided into two groups. Each idea generation session took around 5-10 min. After each round of an idea generation session, each group was asked to briefly present their design ideas to the other group and discuss them. This stage took around 30-40 min. During the workshop, the researcher played the role of moderator. For data presentation purposes, the 10 general consumers are referred to as G1 to G10.

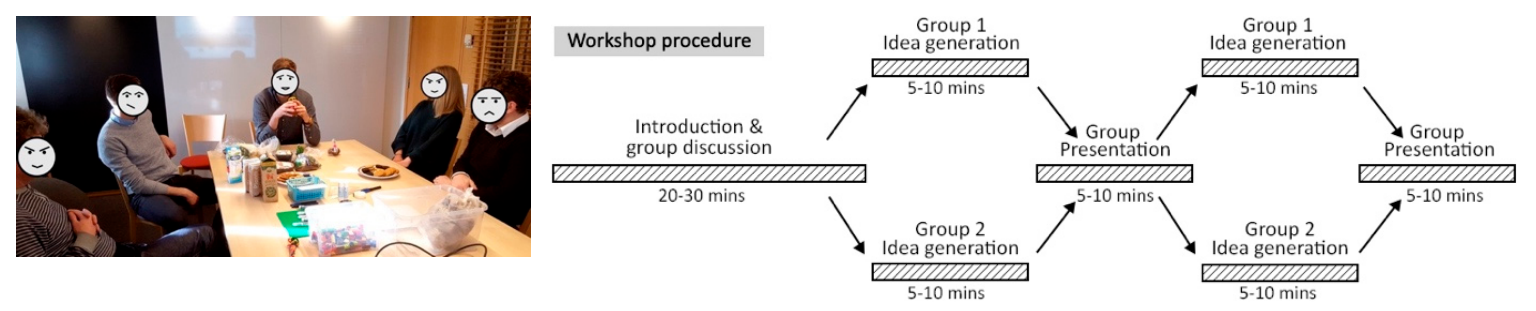

Figure 5. Consumer workshop process.

\subsubsection{Industry Practitioner Interviews}

The focus of the industry practitioner interviews was to collect their personal insights regarding date and storage labeling issues. 10 industry practitioners from Australia were recruited to participate 
in the semi-structured interview. They were selected from the authors' professional networks based on their interest to participate and their professional working experience in the food and packaging industry. Among the participants, 4 were senior packaging experts from food and packaging research organizations and 6 participants were from the food and packaging manufacturing industry. Their occupations varied from food and packaging researcher and packaging development director to company founder and chief executive officer. Given the wide variety of participant backgrounds, interview protocols were tailored to each participant's background. The industry practitioners were referred to as I1 to I10.

Similar to the consumer workshop procedures, we first started the interview by introducing the general date and storage labeling issues. Given the fact that industry practitioners are also ordinary consumers of food products, we encouraged them to first briefly reflect on their own usage of date and storage labels in their everyday life contexts. Then we asked the participants to shift their role back to industry practitioners. We deliberately added a perspective statement before each interview question, for example, "from a general consumer's perspective" or "from an industry practitioner's perspective." In four individual face-to-face interview sessions, we also carried out an individual idea generation session with the participant. These participants sketched or wrote down their design ideas for improving labeling. Each interview session lasted approximately 45 to $65 \mathrm{~min}$.

\section{Results of the Literature Review}

\subsection{An Overview of Date and Storage Labeling Studies}

The 27 papers included in the final full-text review can be further categorized into subgroups based on their research perspectives and focuses (see Table 2). First, we sorted the papers according to their research perspective. Two main research perspectives can be identified: (1) consumer behavior perspective (21 papers), (2) industry practice and labeling regulation perspective (6 papers). Studies conducted from a consumer behavior perspective generally focused on understanding how consumers perceive and use different methods to determine food edibility. Studies conducted from an industry practice and labeling regulation perspective engage with labeling issues by investigating how food manufacturers' and retailers' business practices and governmental regulations can influence consumer behavior. As can be seen in Table 2, compared with the consumer behavior perspective, the perspectives of industry practices and labeling regulations have been less explored.

Four specific research focuses emerged from the results: (1) addressing food waste issues, that is, focusing on how consumer food consumption behavior and industry practices created labeling-related food waste. 15 papers, including 4 papers conducted from the industry and regulation perspective, were identified in this group. (2) Addressing food safety issues, that is, how potential food safety problems can be caused by date labeling. Studies identified in this group explicitly indicated the relation between date labels and food-borne illness across different socio-demographical groups. 9 papers, including 3 papers from the industry and regulation perspective, were identified in this group. This supports the research scope that we determined in this study, that although we are specifically focusing on addressing labeling-related food waste issues, potential food safety risks should not be overlooked or excluded in the scope of this study. (3) Consumers' interpretations of the meaning of date and storage labels, that is, understanding how different label terminologies contribute to misunderstanding both by consumer and industry practitioners. 7 papers, including 1 paper from the industry and regulation perspective, were identified in this group. (4) Food edibility assessment methods in household contexts, that is, understanding consumers' decision-making mechanism of whether to consume or discard food. Papers included in this group mainly discussed the relation between the use of date labels and sensory assessments. 6 papers, all conducted from the consumer behavior perspective, were identified in this group. Note that given the fact that some of the papers have several focuses, one paper may appear in different groups. For instance, some studies with a 
focus on addressing food waste issues also investigated how consumers assess food edibility, thus they were also included in the food edibility assessment group.

Table 2. A mapping of date and storage labeling studies.

\begin{tabular}{|c|c|c|}
\hline Research Focuses & Consumer Behavior Perspective & $\begin{array}{c}\text { Industry Practices and Labeling } \\
\text { Regulations Perspective }\end{array}$ \\
\hline Addressing food waste issues & $\begin{array}{l}\text { Wilson et al. [55] } \\
\text { Wilson et al. [56] } \\
\text { Thompson et al. [57] } \\
\text { Roe et al. [58] } \\
\text { Toma et al. [8] } \\
\text { Hebrok and Heidenstrøm [14] } \\
\text { Abeliotis et al. [23] } \\
\text { Yngfalk [39] } \\
\text { Williams et al. [22] } \\
\text { Watson and Meah [59] } \\
\text { Wikström et al. [21] }\end{array}$ & $\begin{array}{l}\text { Aschemann-Witzel et al. [60] } \\
\text { Milne [9] } \\
\text { Newsome et al. [24] } \\
\text { Woolley et al. [33] }\end{array}$ \\
\hline Addressing food safety issues & $\begin{array}{l}\text { Dickinson et al. [61] } \\
\text { Lenhart et al. [62] } \\
\text { Daelman et al. [63] } \\
\text { Watson and Meah [59] } \\
\text { Wansink and Wright [64] } \\
\text { Terpstra et al. [65] }\end{array}$ & $\begin{array}{l}\text { Ceuppens et al. [66] } \\
\text { Milne [9] } \\
\text { Ransom [67] }\end{array}$ \\
\hline $\begin{array}{l}\text { Consumers' interpretations over } \\
\text { the meanings of date and } \\
\text { storage labels }\end{array}$ & $\begin{array}{l}\text { Wilson et al. [56] } \\
\text { Hall-Phillips and Shah [19] } \\
\text { Van Boxstael et al. [68] } \\
\text { Lenhart et al. [62] } \\
\text { Abeliotis et al. [23] } \\
\text { Labuza et al. [27] }\end{array}$ & Newsome et al. [24] \\
\hline $\begin{array}{l}\text { Food edibility assessment } \\
\text { methods in household contexts }\end{array}$ & $\begin{array}{l}\text { Hebrok and Heidenstrøm [14] } \\
\text { Samotyja [69] } \\
\text { Yngfalk [39] } \\
\text { Van Boxstael et al. [68] } \\
\text { Terpstra et al. [65] } \\
\text { Corradini [34] }\end{array}$ & $\begin{array}{l}\text { No relevant papers (in the scope of } \\
\text { this literature review) }\end{array}$ \\
\hline
\end{tabular}

\subsection{Compiling Literature Results through an AT Theoretical Lens}

According to AT, human activity is driven by motivations directed toward goals. In the context of this study, the overarching motivation for consumers to judge food edibility can be simply described as to determine whether food is good to eat or should be discarded. This motivation can be further broken down into three specific goals: assess food safety, assess food quality and avoid unnecessary food waste. In order to achieve these goals, three mediating tools (as defined in Section 2) are commonly used by consumers in their food consumption activities: "Use by" date, "Best before" date and sensory perceptions with past experience. By using AT as an analytical tool for synthesizing the literature result, a general procedure of how the consumer uses the internal mediating tools (sensory perception with past experience) and external mediating tools ("Use by date" and "Best before" date) to achieve the specific goals in food edibility assessment activity system is illustrated in Figure 6. To be more specific, papers in the group of "food edibility assessment methods in household contexts" were mainly used to develop a holistic view of the interplay between different goals and mediating tools (illustrated as A1, B1, C1, C2, D1 and D2 in Figure 6). Subsequently, papers in the group of "consumers' interpretations on the meanings of date and storage labels" were mainly used to develop insights regarding how consumers interpret and use both the "Best before" date and "Use by" date (illustrated as A1, C1 and D1). Papers in the group of "addressing food safety issues" were mainly used to constitute the insights of how consumers use the "Use by" date (illustrated as C1 and C2), and papers identified in the group 
of "addressing food waste issues" were used to develop the insights of how consumers use the "Best before" date (illustrated as D1 and D2).

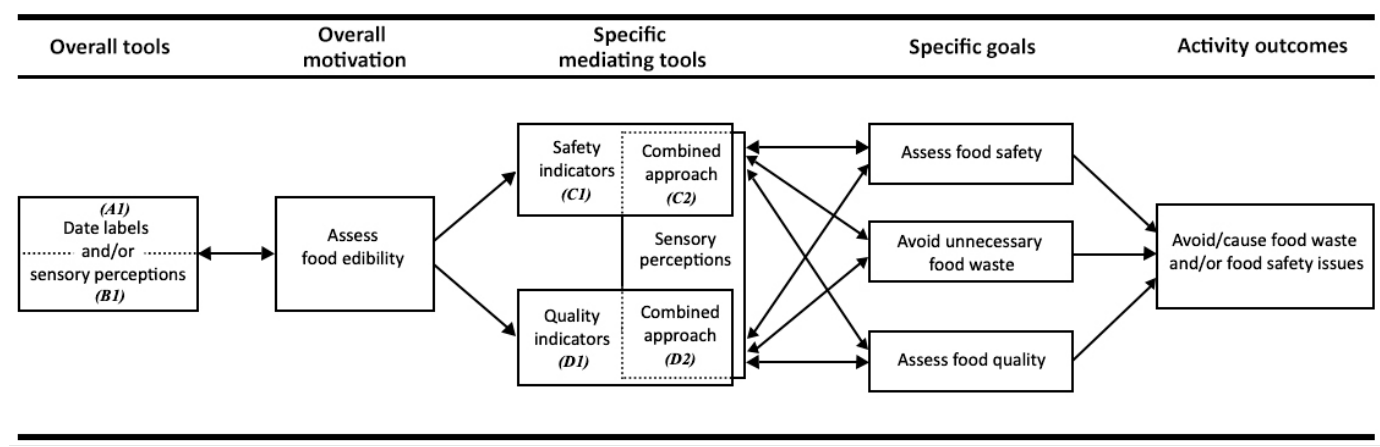

Figure 6. The interplay between consumers' specific goals and the use of sensory perceptions and date and storage labels in a food consumption activity system.

\subsubsection{Consumers' Perception and Use of Date and Storage Labels}

Literature in this theme (see the theme A1 in Figure 6 and Table 3) focuses on addressing questions such as how consumers interpret the meanings of date and storage labels, whether and why there are any confusions caused by the labels, and what consequences can be caused by the confusions.

Regarding consumers' perception of date and storage labels, many studies included in the literature review indicated that consumers lack correct understandings on different labeling terminologies. In particular, consumers are confused over the meanings of "Best before" and "Use by" dates $[8,11,12,16,23,27,66,68]$. Moreover, various formats and displays of date labels can create further confusion for consumers when they check date and storage information on packaging $[17,19,26]$. In order to solve this problem, proposals for action were made for food manufacturers and retailers to move toward better labeling uniformity. Common suggestions include allocating one type of products with only one type of labels $[24,26,66]$, ensuring the labels on packaging are visible and easy to read by consumers $[19,27,46,70-72]$ and improving consumer knowledge on the meaning of "Use by" and "Best before" through education campaigns [23,70,71].

Regarding consumers' real usage of labels, a gap between labeling information presentation and information usage in consumer food consumption has been identified by Lyndhurst [73]. In other words, a better label presentation does not always necessarily lead to better labeling usage in consumers' real food consumption. To be more specific, although some consumers explicitly expressed the needs for clear shelf life and storage information, they still tend to neglect the relevant information that is already existed on packaging $[21,74]$. For instance, it was found that only approximately half of the consumers in Belgium follow date labels as guidance in their food assessment activities [68]. In order to bridge this gap, various consumer behavior change interventions were proposed in the literature. The commonality among these interventions was the emphasis of communicating date labeling information at consumers' real food-handling contextual settings [12,14]. For instance, education campaigns about helping consumers to better understand label differences were regarded as more effective at the point of sale $[15,24,62]$. The explanation of different labeling terminology was better perceived by consumers if it was written on pamphlets and signage in supermarkets or restaurants where consumers are carrying out food consumption activities [21,74]. Additionally, many studies pointed out that product packaging is an effective information carrier for raising consumer awareness and changing behavior. Instead of only providing data and storage related information, packaging can also present the impact of food waste issues to consumers [25]. Moreover, a detailed explanation of labeling terminologies and storage methods should also be included on product packaging $[8,21,75]$. 


\subsubsection{Consumers' Embodied Knowledge and Use of Sensory Perceptions in Relation to Date Labels}

Literature in this theme (see the theme B1 in Figure 6 and Table 3) mainly focuses on studying how consumers use their own sensory perceptions in relation to date labeling to judge food edibility. It was pointed out in the literature that consumers' greater sensory acceptance of food items can keep down food waste [76]. However, the overreliance on date labels may largely constrain consumers' sensory assessment abilities $[17,39,59]$.

The sensory perceptions that consumers commonly use are vision and smell, followed by taste [68]. Different food attributes (e.g., off flavor, discoloration, odor, texture) are evaluated by consumers against their embodied knowledge and past experience [34]. Consumers are willing to trust their own sensory perceptions when there is an obvious deterioration sign or no dating information on food items [69]. However, the absence of dating information is likely to lead to unnecessary food waste if consumers don't possess sufficient confidence and knowledge in their sensory assessments. In this case, the consumers are more likely to apply their rule of thumb and directly discard in-doubt products [34]. This argument is further supported by a laboratory experiment that investigated how consumers react to the presence and absence of date information on milk products [58]; the result showed that more participants chose to discard perfectly edible milk samples when date labeling was absent and thus sensory assessments became the only means. In addition, the lack of basic food handling knowledge can also lead to the waste of edible food. For example, Labuza et al. [27] pointed out that consumers are lacking in the knowledge of proper temperature control for food stored at home. Toma et al. [8] also identified that consumers have become less knowledgeable of food attributes that can be used as sensory criteria to assess food quality and safety status.

To address these tensions, proposals for action have been made to empower consumers' confidence and embodied knowledge in using their sensory perceptions [14,58]. Communicating food-handling knowledge to consumers was regarded as the most direct solution $[19,65]$. Product packaging was regarded as a potential mediating tool to communicate such knowledge to consumers. Specifically, Williams et al. [22], Wikström et al. [21] and Aschemann-Witzel et al. [60] proposed a similar idea that packaging can be designed to encourage consumers to first have a little taste of the content and then make a judgment. From the perspective of food manufacturers and retailers, Lenhart at al. [62] argued that food industry practitioners should be encouraged to provide more detailed guidance about food storage and handling on product packaging, especially for products that have to be refrigerated in a household environment. From a date labeling design perspective, Toma et al. [8] indicated that since consumers tend to become less experienced in using sensory perceptions to make food edibility judgments, information about date labeling should be presented in a clearer way on product packaging.

\subsubsection{Tensions within Consumer Interaction with "Use by" Date}

As illustrated in the themes $\mathrm{C} 1$ and $\mathrm{C} 2$ in Figure 6 and Table 3, literature in these themes mainly centers on how consumers interact with the "Use by" date. Although many studies indicated that the "Use by" date was considered by consumers as more helpful for indicating food safety than other types of date labels $[55,62,67,77,78]$, the effects of the "Use by" date to consumers still vary across different case scenarios. When it comes to the scenario in which the consumer needs to make a trade-off between food waste and safety, some consumers tend to prioritize reducing waste and thus consume food that passed the "Use by" date, which may lead to the risk associated with food-borne illness [59,61]. For instance, study results from Daelman et al. [63] indicated that only half of the respondents tend to follow the "Use by" date on refrigerated and processed food, and the majority of the remaining respondents would still consume the product after the date due to their concerns about food waste.

In addition to that, in some cases, consumers regard their own sensory assessment as a more reliable means than following the "Use by" date $[59,61,65]$. This is due to two reasons; first, if consumers are familiar with a particular food item, they are more likely to rely upon their sensory perceptions and past experience as the only means for judgment $[17,35,74,79]$. Second, some consumers lack trusts in date labeling, thus they tend to ignore the "Use by" date and follow their own judgment [57]. As a 
result, when used in conjunction with "Use by" date labels, sensory perceptions can bring benefits as well as potential risks. On the one hand, the correct knowledge and skills of using sensory assessments may work as an extra insurance for consumers to avoid waste of edible food. On the other hand, existing studies also pointed out the particular concern that consumers, being overconfident in their sensory perceptions, may have the possibility to impede themselves from strictly following the "Use by" date $[17,35,74,79]$. Therefore, some consumers would trust their sensory perceptions more than the recommended last day of consumption on "Use by" labels. In this case, if the consumer does not have the proper sensory judgment knowledge and skills, it may lead to problems associated with food safety.

In order to address the tensions pointed out by the existing literature, proposals for action have been made mainly at tailoring information to consumers' needs and improving their food handling knowledge. For example, communicating labeling-related knowledge to special groups of consumers such as elderly people and pregnant women to meet their particular interests related to food safety [62]; providing additional information such as specific cooking recipes to guide consumers to use products that almost reach their shelf life [60]; and helping consumers to keep track of product "Use by" dates through mobile applications [24]. However, the challenge of how to balance people's use of their own sensory assessments and the authority of the "Use by" date remained unsolved in the existing body of the reviewed literature.

Another tension that the consumer encounters during food consumption activity is how long a product can be safely eaten after the first opening $[65,73]$. On the one hand, some consumers do not know that the "Use by" date ceases to apply when the product has been opened. On the other hand, opened products can be discarded and turned into food waste as consumers are uncertain of the remaining shelf life [75]. To solve this particular problem, additional date instructions such as "Use within X days after opening" are considered a helpful guidance $[67,73,75,80]$. However, food manufacturers and retailers face difficulty in measuring the shelf life of opened products. Due to the variety and unpredictability of consumers' household storage conditions such as temperature control in the refrigerator, "Use within X days after opening" is only a rough estimation of product shelf life in a household environment $[75,80]$. In order to make this date instruction more accurate and effective, proposals for action have been made to better combine the meaning of this specific date label with education campaigns to guide consumers to store opened food products more properly $[73,75]$. Detailed questions such as where and how to store a particular product to optimize its shelf life in a household environment can be covered in such education campaigns [19,62]. In addition to that, smart labels such as time-temperature indicators (TTIs) were suggested to inform consumers about products' remaining shelf life after opening. Compared with the "Use within X days after opening" label, which is static and pre-defined based on certain estimation, time-temperature indicators can dynamically present product conditions in real time [22,29]. However, based on our literature review, the influences of TTIs on consumers' real food consumption contexts have rarely been explored.

\subsubsection{Tensions within Consumer Interaction with "Best Before" Date}

As illustrated in the themes D1 and D2 in Figure 6 and Table 3, literature in these themes mainly centers on the unnecessary food waste caused by the consumer's incorrect usage of the "Best before" date. The key tension identified in this category is that consumers discard food that passed the "Best before" date without assessing the real quality of the content.

Although some consumers can correctly understand the "Best before" date as a quality indicator, they still tend to discard food that passed or is near the "Best before" date $[11,23,28,56,80]$. The reason behind this phenomenon is probably due to the excessive concerns that consumers hold over food quality, believing that fresh food is always healthier than food that is close to its expiry date. This perception is, to a large extent, misled by the food industry's overemphasis on the importance of food freshness attributes in consumption [60]. In addition, it was pointed out in the literature that the use of sensory perceptions in conjunction with "Best before" date labels is more likely to reduce 
the variability of household food wastage $[12,17]$. However, when it comes to how to better combine sensory assessments with the "Best before" date, few explicit proposals for action have been made in the reviewed literature.

To solve this problem, education campaigns towards empowering thriftiness and reducing food waste were regarded as a promising method $[58,59]$. This is further supported by a packaging and food waste study conducted by Williams et al. [22], in which food waste of 61 households in Sweden was analyzed, indicating that environmentally educated households wasted less food that passed its "Best before" date. Except for the education campaigns, many studies have proposed that product packaging can be used to provide consumers with additional information about how to better use the "Best before" date $[8,14,21,22,58,60]$. This information includes detailed explanation of the meaning of the "Best before" date $[23,70,71]$; explicit guidance about whether it is safe to taste the content and then make a judgment [21,22,60]; innovative ways to show product freshness on packaging [19,79]; tips about how to better assess product freshness by using sensory perceptions [14,58]; and brief descriptions about food waste issues [58]. 
Table 3. A summary of tensions and proposals for actions identified in the reviewed literature.

\begin{tabular}{|c|c|c|c|c|}
\hline Actions and Mediating Tools & Specific Tensions & Corresponding Behavior & Potential Outcomes & Corresponding Proposals for Action \\
\hline \multirow[t]{4}{*}{$\begin{array}{l}\text { (A1). } \\
\text { Consumer perception and usage } \\
\text { of date labels }\end{array}$} & $\begin{array}{l}\text { Lack of adequate explanation of } \\
\text { different label terminologies }\end{array}$ & $\begin{array}{l}\text { Some consumers refuse to trust date labels and lack of } \\
\text { correct understandings on different date labeling } \\
\text { terminologies }[17,25-27,59,61,70] \text {. } \\
\text { Consumers are confused over the differences between } \\
\text { "Best before" and "Use by" dates }[8,11,12,16,23,27,66,68] \text {. }\end{array}$ & $\begin{array}{l}\text { Lead to problems mainly } \\
\text { associated with food waste }\end{array}$ & $\begin{array}{l}\text { Consumer education campaigns: } \\
\text { Education campaigns are necessary to help consumers } \\
\text { understand different date labels }[24,56,71] \text {. } \\
\text { Improve consumer knowledge on the "Use by" date and } \\
\text { "best before" date }[23,70,71] \text {. }\end{array}$ \\
\hline & $\begin{array}{l}\text { Lack of consistency on label } \\
\text { content and display }\end{array}$ & $\begin{array}{l}\text { Most of the consumers interpret date labels with variation } \\
\text { depending upon the type of food product under } \\
\text { consideration [68]. } \\
\text { Various formats and displays of date labels create } \\
\text { confusions when consumers need to check date } \\
\text { information }[17,19,26] \text {. }\end{array}$ & $\begin{array}{l}\text { Lead to problems mainly } \\
\text { associated with food waste }\end{array}$ & $\begin{array}{l}\text { Move towards better label uniformity: } \\
\text { To allocate to one food category one type of date label } \\
\text { and storage guidance to ensure uniformity }[24,26,66] \text {. } \\
\text { Food and packaging industry practitioners need to } \\
\text { standardize and ensure date and storage information on } \\
\text { packaging are visible and easy to follow by consumers } \\
{[12,19,27,46,70-72] \text {. }}\end{array}$ \\
\hline & \multirow[t]{2}{*}{$\begin{array}{l}\text { The gap between information } \\
\text { presentation and usage }\end{array}$} & \multirow[t]{2}{*}{$\begin{array}{l}\text { The percentage of consumers who use on-pack date labels } \\
\text { as guidance for assessing food is estimated to be } \\
\text { approximately } 50 \% \text { [ } 68] \text {. } \\
\text { Consumers expressed the need for clear on-pack shelf life } \\
\text { and storage information; however, they did not use the } \\
\text { information that already existed on packaging }[21,74] \text {. }\end{array}$} & \multirow[t]{2}{*}{$\begin{array}{l}\text { Lead to problems mainly } \\
\text { associated with food waste }\end{array}$} & $\begin{array}{l}\text { Communicate knowledge in activity contextual } \\
\text { settings: } \\
\text { Education and awareness campaigns are insufficient in } \\
\text { achieving food waste reduction. Date and storage } \\
\text { labeling need to be communicated at consumers' real } \\
\text { food-handling contextual setting [14]. } \\
\text { Consumers would like to receive the meaning of date } \\
\text { labels through point-of-purchase pamphlets, cookbooks, } \\
\text { and restaurants [15,62]. } \\
\text { Potential material for date label explanation includes } \\
\text { signage, other materials at the point of sale and QR } \\
\text { codes [24]. }\end{array}$ \\
\hline & & & & $\begin{array}{l}\text { Packaging can be improved to provide consumers with } \\
\text { more detailed information on shelf life and storage } \\
\text { methods in the contextual moments when the food item } \\
\text { is used }[8,21,75] \text {. } \\
\text { Impacts of food waste and safety information can be } \\
\text { presented on packaging along with date information to } \\
\text { raise consumer awareness [25]. } \\
\text { Incorporate new technologies to indicate shelf life: } \\
\text { Use smart/intelligent labels to indicate whether the food } \\
\text { item is safe or of high quality }[21,28,80] \text {. }\end{array}$ \\
\hline $\begin{array}{c}\text { (B1). } \\
\text { Consumer sensory assessment }\end{array}$ & $\begin{array}{c}\text { Lack of confidence in sensory } \\
\text { assessments }\end{array}$ & $\begin{array}{l}\text { Some consumers seem to solely rely on date labels to } \\
\text { judge food edibility, which may largely constrain their } \\
\text { own sensory assessment abilities [17,39,59]. } \\
\text { Consumers are insecure in using their sensory } \\
\text { assessments for specific food products (e.g., milk), the } \\
\text { absence of a date label on those food products appears to } \\
\text { induce more discards of in-date food [58]. } \\
\text { Consumers often follow the rule of thumb "when in } \\
\text { doubt, throw it out" in their food disposal } \\
\text { decision-making process [34]. }\end{array}$ & $\begin{array}{l}\text { Lead to problems mainly } \\
\text { associated with food waste }\end{array}$ & $\begin{array}{l}\text { Improve general food-related knowledge: } \\
\text { Empower consumer knowledge in using their sensory } \\
\text { assessments and reduce consumers' insecurity } \\
\text { feelings }[14,58] \text {. } \\
\text { Introduce packaging-related intervention: } \\
\text { Packaging can be used to explicitly inform consumers } \\
\text { that it is safe to taste the content or use other senses for } \\
\text { assessments }[21,22,60] \text {. }\end{array}$ \\
\hline
\end{tabular}


Table 3. Cont.

\begin{tabular}{|c|c|c|c|c|}
\hline Actions and Mediating Tools & Specific Tensions & Corresponding Behavior & Potential Outcomes & Corresponding Proposals for Action \\
\hline & $\begin{array}{l}\text { Lack of knowledge in } \\
\text { food handling }\end{array}$ & $\begin{array}{l}\text { Consumers have become less knowledgeable of food } \\
\text { attributes associated with both safety and quality [8]. } \\
\text { Consumers are lacking in basic food safety handling skills, } \\
\text { such as lack of temperature control for food at home [27]. }\end{array}$ & $\begin{array}{l}\text { Lead to problems mainly } \\
\text { associated with food waste }\end{array}$ & $\begin{array}{l}\text { Provide general food handling knowledge guidance } \\
\text { on packaging: } \\
\text { Consumers need education about safe food storage and } \\
\text { handling }[19,65] \text {. } \\
\text { Need for clearer information about date marking on } \\
\text { packaging since consumers have become less } \\
\text { knowledgeable of the food attributes associated with } \\
\text { safety and quality and rely increasingly on food label } \\
\text { instructions [8]. } \\
\text { Food manufacturers and retailers are encouraged to } \\
\text { provide more information on safe storage and handling } \\
\text { of refrigerated products on package labels [62]. }\end{array}$ \\
\hline \multirow[t]{2}{*}{$\begin{array}{l}\text { (C1). } \\
\text { Safety indicator: "Use by" date }\end{array}$} & $\begin{array}{l}\text { The safety effects of the "Use by" } \\
\text { date vary across different cases }\end{array}$ & $\begin{array}{l}\text { "Use by" dates were considered by consumers as more } \\
\text { helpful for indicating food safety than other labels } \\
{[55,62,67,77,78] \text {. }} \\
\text { Only half of the respondents tend to follow "Use by" dates } \\
\text { indicated on refrigerated and processed products [63]. } \\
\text { Some consumers are more concerned with food waste } \\
\text { issues, thus eat food that has passed its "Use by" } \\
\text { date }[59,61] \text {. } \\
\text { Pregnant women and parents with kids read label } \\
\text { instructions more frequently than senior people who tend } \\
\text { to only use their own sensory perceptions to make } \\
\text { judgments }[12,65,81] \text {. }\end{array}$ & $\begin{array}{l}\text { Ensured food safety in some } \\
\text { cases but compromised safety } \\
\text { issues on others. }\end{array}$ & $\begin{array}{l}\text { Tailor label communication to meet consumers' } \\
\text { particular needs: } \\
\text { Communication will need to focus on addressing } \\
\text { consumer risk perceptions and label trust issues [57]. } \\
\text { Communicate date label-related knowledge to the } \\
\text { special groups of consumers such as elderly people, } \\
\text { pregnant women, and people who are } \\
\text { immune-compromised, to meet their particular interests } \\
\text { and needs [62]. } \\
\text { Expand date label information to include guidance (e.g., } \\
\text { recipes) that can help consumers to solve tradeoffs } \\
\text { between food safety and waste [60]. } \\
\text { Help consumers to better manage food items in the } \\
\text { household: } \\
\text { Transferring product Use-by dates to consumers' mobile } \\
\text { devices to remind consumers to eat the product in } \\
\text { time [33]. }\end{array}$ \\
\hline & $\begin{array}{l}\text { Inadequate date and storage } \\
\text { guidance on opened products }\end{array}$ & $\begin{array}{l}\text { Some consumers do not know that the "Use by" date } \\
\text { ceases to apply when the product has been opened, while } \\
\text { some discard the opened food items due to uncertainty of } \\
\text { the remaining shelf life }[65,73,75] \text {. } \\
\text { For refrigerated food products, label instructions about } \\
\text { when to discard the products after opening were } \\
\text { considered helpful by consumers [62,75]. } \\
\text { The food industry faces the difficulty in measuring the } \\
\text { shelf life of opened products }[75,80] \text {. }\end{array}$ & $\begin{array}{l}\text { Lead to problems associated } \\
\text { with both food safety and waste }\end{array}$ & $\begin{array}{l}\text { Improve date label statement and education: } \\
\text { Labels such as "Use within } X \text { days after opening" might } \\
\text { be more effective if combined with education campaigns } \\
\text { such as temperature control at home }[67,73,75,80] \text {. } \\
\text { Consumers need education on specific guidelines such } \\
\text { as where to store and how to assess products that have } \\
\text { been opened }[19,62,73,75] \text {. } \\
\text { Use smart labels to indicate shelf life: } \\
\text { Date labels combined with time-temperature indicators } \\
\text { (TTIs) can inform consumers the remaining shelf life in } \\
\text { real time [27,34]. } \\
\text { Develop technologies at the household level (e.g., } \\
\text { mobile applications) to help consumers to better manage } \\
\text { their food items and track the expiration date [24]. }\end{array}$ \\
\hline $\begin{array}{l}(\mathrm{C} 2) . \\
\text { "Use by" date used in } \\
\text { conjunction with sensory } \\
\text { perceptions }\end{array}$ & $\begin{array}{l}\text { Potential risks of overreliance } \\
\text { on sensory assessments for food } \\
\text { safety judgment }\end{array}$ & $\begin{array}{l}\text { Some consumers regard their own sensory assessments as } \\
\text { a more reliable way to judge food safety than the "Use by" } \\
\text { labels }[59,61,65] \text {. } \\
\text { Consumers tend to apply their sensory perceptions and } \\
\text { past experience when they are familiar with the particular } \\
\text { food products under concern }[17,35,74,79] \text {. }\end{array}$ & $\begin{array}{l}\text { Lead to problems mainly } \\
\text { associated with food safety }\end{array}$ & No results based on our literature review. \\
\hline
\end{tabular}


Table 3. Cont

\begin{tabular}{|c|c|c|c|c|}
\hline Actions and Mediating Tools & Specific Tensions & Corresponding Behavior & Potential Outcomes & Corresponding Proposals for Action \\
\hline $\begin{array}{l}\text { (D1and D2). } \\
\text { Quality indicator: "Best } \\
\text { before" date }\end{array}$ & $\begin{array}{l}\text { Foods that reach the "Best } \\
\text { before" date turned into } \\
\text { food waste }\end{array}$ & $\begin{array}{l}\text { Consumers waste edible products with a "Best before" } \\
\text { date as the product is close to or passes the } \\
\text { date }[11,23,28,56,75] \text {. } \\
\text { Food marketing communication may have } \\
\text { overemphasized food quality and freshens attributes } \\
\text { rather than consumers' actual needs [60]. } \\
\text { The use of sensory perceptions in conjunction with "Best } \\
\text { before" date labels is more likely to reduce the variability } \\
\text { of household food wastage [12,17]. }\end{array}$ & $\begin{array}{l}\text { Lead to problems mainly } \\
\text { associated with food waste }\end{array}$ & $\begin{array}{l}\text { Present date label-related information on packaging: } \\
\text { Product packaging can be used to explain how to better } \\
\text { follow the "Best before" date }[8,14,21,22,58,60] \text {. } \\
\text { Develop on-pack label innovations which can provide } \\
\text { consumers with additional product freshness and/or } \\
\text { quality information [19,79]. } \\
\text { Consumer education campaign: } \\
\text { Enhance consumer education about how to use "Best } \\
\text { before" date labels and their connection to food waste } \\
\text { issues [58]. } \\
\text { A different focus for food waste interventions is to } \\
\text { enable people to enact thriftiness [59] }\end{array}$ \\
\hline
\end{tabular}




\subsection{AT-based Conceptual Model of Tensions and Proposals for Actions in Food Edibility Assessment System}

Based on the literature review results, we summarized and mapped the identified tensions in a conceptual model. According to the AT theoretical lens that we applied in the study, the identified tensions were further categorized into four groups (as illustrated in Figure 7).

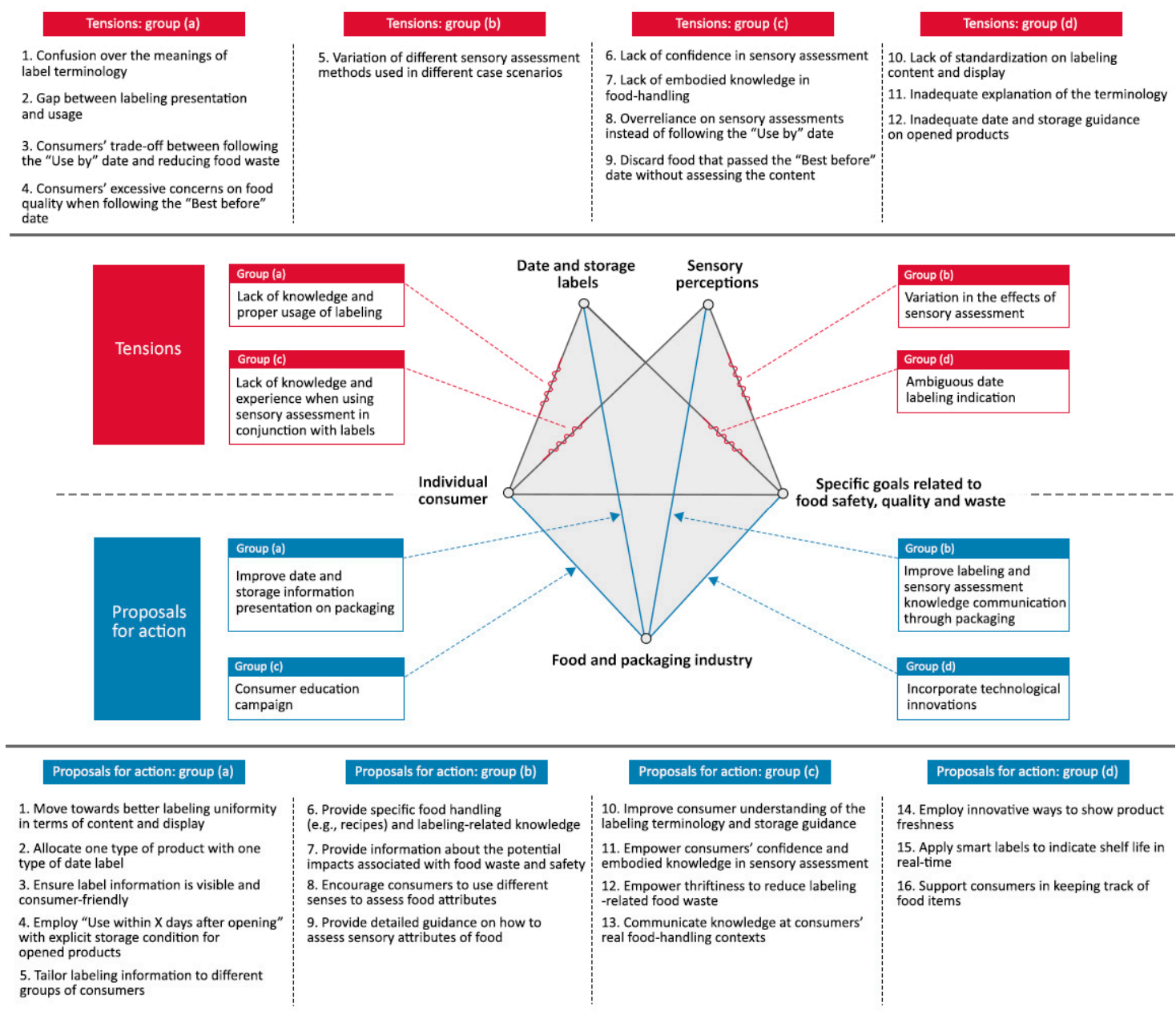

Figure 7. A conceptual model for mapping the tensions and proposals for action identified in the literature review.

Tensions group (a): consumers' lack of knowledge and proper usage of date and storage labeling. From an AT perspective, this group summarizes the tensions between consumers and date labeling which are regarded as the external mediating tool used in food edibility assessment. We focus on summarizing problems that the consumer encounters when interacting with date labeling in their food consumption activities. Specifically, this group consists of: (1) consumer confusion over the meanings of label terminology (e.g., the meaning of the "Best before" and "Use by" date) (elaborated in Section 4.2.1), (2) a gap between labeling information presentation and information usage (elaborated in Section 4.2.1), (3) a variation in the effects of the "Use by" date in relation to food disposal decisions especially when consumers face the trade-off between following the "Use by" date and reducing food waste (elaborated in Section 4.2.3) and (4) a variation in the effects of the "Best before" date especially in the case where consumers hold excessive concerns on the potential impacts of food shelf life-related quality issues (elaborated in Section 4.2.4).

Tensions group (b): variation in the effects of sensory assessment. In this group, we focus on summarizing the tensions between sensory perceptions (the internal mediating tool) and the specific goals that consumers aim to achieve in their food edibility assessment activities. This group is mainly 
about (5) a variation of sensory assessment criteria and methods used in different case scenarios with different food products (elaborated in Section 4.2.2).

Tensions group (c): consumers' lack of embodied knowledge and experience when using sensory assessment in conjunction with labels. This group summarizes the tensions between consumers and their use of sensory perceptions (internal mediating tool). Specifically, we focus on summarizing problems that consumers encounter when using sensory perceptions to make food edibility judgments. This group consists of: (6) a lack of confidence in using sensory assessment in conjunction with date labels (elaborated in Section 4.2.2), (7) a lack of embodied knowledge in sensory perceptions and food handling (elaborated in Section 4.2.2), (8) an overreliance on sensory assessments instead of strictly following the suggested "Use by" date on packaging (elaborated in Section 4.2.3) and (9) discard food that passed the "Best before" date without assessing the quality attributes of the content (elaborated in Section 4.2.4).

Tensions group (d): ambiguous date labeling indication and a lack of standardization. In this group, we focus on summarizing the tensions between date labeling (external mediating tools) and the specific goals that consumers aim to achieve. In other words, date and storage labels in some cases are insufficient to meet consumers' food safety and waste prevention goals due to some specific packaging-related limitations. These limitations include: (10) a lack of consistency and standardization of labeling content and display (elaborated in Section 4.2.1), 11) an inadequate explanation of the labeling terminology on packaging and (12) an inadequate date and storage guidance on opened products (elaborated in Section 4.2.3).

Correspondingly, based on the literature review results and the AT theoretical lens, we also summarized and categorized the labeling-related proposals for action into four groups (see Figure 7).

Proposals for action group (a): improve date and storage information presentation on packaging. The proposals for action categorized in this group mainly focus on how to better present and communicate date and storage information on packaging. Specifically, this group consists of: (1) move towards better labeling uniformity in terms of terminology, content and display (see Section 4.2.1), (2) allocate one type of product with only one type of label (see Section 4.2.1), (3) ensure label information is visible and consumer-friendly (see Sections 4.2.1 and 4.2.2), (4) employ a "Use within X days after opening" label description with explicit storage condition for opened products (see Section 4.2.3) and (5) tailor date and storage-related information for certain groups of consumers such as pregnant women and elderly people who pay special attention to food shelf life attributes (see Section 4.2.2).

Proposals for action group (b): improve labeling and sensory assessment knowledge communication through packaging. Compared with the group (a), the proposals for action categorized in this group view packaging as not only information carriers that present labeling-related information to consumers, but also as effective mediators which can be used to raise public awareness of food waste and change individual consumption behavior. Specifically, these proposals for action aimed to: 6) provide specific food-handling information (e.g., how to store food in the household environment and how to use food that is close to the expiration date) and date labeling-related knowledge such as the meaning of the "Best before" and "Use by" dates on packaging (see Sections 4.2.1 and 4.2.4), (7) provide information regarding the potential individual and environmental impacts associated with food safety and food waste issues on packaging (see Sections 4.2.1 and 4.2.4), 8) encourage consumers to use different senses to assess food attributes (see Sections 4.2.2 and 4.2.4) and 9) provide detailed guidance on how to assess sensory attributes of food through packaging design (see Section 4.2.2 and Section 4.2.4).

Proposals for action group (c): consumer education campaign. The proposals for action categorized in this group mainly focus on increasing consumer labeling-related knowledge through education campaigns. Specifically, these proposals for action include: 10) improve consumer understanding of the differences between the "Best before" date and "Use by" date (see Sections 4.2.1 and 4.2.3), 11) improve consumers' overall confidence and embodied knowledge of using sensory 
assessments (see Section 4.2.2), 12) empower thriftiness to reduce date labeling-related food waste (see Section 4.2.4) and 13) communicate date and storage labeling-related knowledge at consumers' real food-handling contextual settings, such as through signage, leaflet and QR codes at the point of sale (see Section 4.2.1).

Proposals for action group (d): incorporate technological innovations. The proposals for action categorized in this group aim at implementing technological solutions to better present food quality status and create new ways of communicating shelf life information to consumers. This group consists of: 14) employ innovative ways to show product freshness on packaging (see Section 4.2.3), 15) apply smart labels (e.g., time-temperature indicator) to detect food quality status and indicate the remaining shelf life in real-time (see Section 4.2.3) and 16) support consumers in keeping track of the shelf life of food items in the household environment (see Section 4.2.3).

\section{Results of Consumer Workshops and Industry Practitioner Interviews}

Applying the tensions and proposals for action we summarized in the conceptual model, we grouped the results from the consumer design workshops and industry interviews into three themes concerning improved date and storage: (1) information presentation on packaging, (2) improved knowledge communication through packaging and (3) technological interventions. (Note that the consumer education campaign was excluded in this part, as it is not directly related to the design perspective that this paper takes). The key findings are presented in the following sections.

\subsection{Improved Date and Storage Information Presentation on Packaging}

Consumer and industry practitioners had somewhat different ideas about what information the on-pack date and storage label needs to provide (see the summary in Table 4).

Table 4. A summary of participants' feedback regarding label presentation on packaging.

\begin{tabular}{lll}
\hline Proposals for Action & Evaluation from the Consumer Side & \multicolumn{1}{c}{ Evaluation from the Industry Side } \\
\hline Label uniformity & $\begin{array}{l}\text { More descriptive and explanatory } \\
\text { label statements. } \\
\text { Provide detailed storage guidance } \\
\text { (e.g., can it be frozen). } \\
\text { Data visualization of shelf life with the } \\
\text { probability for bacteria to grow. }\end{array}$ & $\begin{array}{l}\text { Conflicting opinions between the "Use by" } \\
\text { date and "Best before" date. } \\
\text { Improve readability: labels should be } \\
\text { clear, stand out, have large fonts and be } \\
\text { less congested. } \\
\text { Avoid wordy and negative information. } \\
\text { Provide detailed descriptions to guide } \\
\text { better storage. }\end{array}$ \\
& $\begin{array}{l}\text { "Use within X days after opening" should } \\
\text { stand out with large fonts. } \\
\text { Adding storage conditions right next to } \\
\text { the “Use within X days after } \\
\text { openning" statement. }\end{array}$ \\
\hline
\end{tabular}

The focus of the consumer workshop was on how to provide a more descriptive explanation of shelf life information. For example, G6 stated that a "Best before but usually good after" statement is much clearer than only showing the "Best before" statement- "They [pointing at milk packaging] have a best before, but under that label, usually good after, so they sort of want to indicate that when it is past the best before, it is not automatically turned bad." Participants also came up with the idea to use graphics to better visualize the shelf life of products, especially for fresh produce such as meat, fish and dairy that may cause food safety issues-for example, G5 stated: "Perhaps a bar that shows now you should cook it and now you should throw it away. Or it can be scales also", G2 stated: "I would also appreciate if there were some sort of graphs, like probability for this kind of bacteria to develop."

The industry participants all expressed the urgent need for the current date labeling systems to move towards uniformity. Specifically, this includes the standardization of both label display and content. In terms of the display, all the industry participants stated that labels should be clear, stand out, 
use large fonts and be less congested so that the readability can be improved. In terms of label content, the industry participants indicated that they prefer to only use a single set of terminology rather than following the dual "Best before" and "Use by" system. However, conflicting opinions regarding which label should be kept and which one should be eliminated were found among the industry interviews. Some participants argued that the "Use by" date should be kept as the only label in the system—for example, I6 stated that "I think use by is a sensible terminology because there are after safety considerations. I think best before just confuses people. And I think for fresh produce, I would get rid of a date label. I would like to see a food safety focus rather than product assurance from an aesthetics focus" (I6). While on the contrary, some tend to put the "Best before "date on their products. One food manufacturer who had recently switched the product labels from "Use by" to "Best before" indicated that the "Best before" date can allow consumers to take more responsibilities when judging food edibility- "I've just changed to a best before, because I would hope that consumers would be able to make that assessment [food edibility assessment]" (I2).

A common suggestion we received from both consumer and industry participants was the importance to show storage methods on packaging in detail. A simple and clear statement of whether the product can be frozen was regarded especially useful- "If it would be information on the cheese that says this cheese would be totally fine if you put it into the freezer, then I would do it directly instead of hesitating as I am now" (G5).

A "Use within X days after opening" label statement was regarded as a promising way to help consumers better manage opened products. However, food manufacturers were often uncertain about the consumer food storage conditions and they have to make some estimation, as I2 indicated: "lab tests, and to be honest it's a bit of a guess, because you're relying on that person to store it properly." Therefore, from both food safety and waste perspectives, the specific storage condition should be placed next to the packaging-"Producers now putting on the pack 'once opened please store it at 5 degrees and use it within in 3 days', that is an example, but that is the kind of instructions which I think are most valuable" (I3). This labeling instruction could also be further combined with the solutions that participants in the design workshop came up with. They pointed out that the problems sometimes were not only related to label readability, but also associated with bad management of opened food items. Therefore, they proposed the solution to put simple stickers or smart indicators on packaging to remind consumers when the product has been opened.

\subsection{Improved Labeling and Sensory Assessment Knowledge Communication through Packaging}

Packaging is not only an information carrier that presents product shelf life information, but it is also a mediator to communicate knowledge and influence consumer behavior. For this theme, the focus was on how to better communicate the embodied sensory and food handling knowledge to consumers through packaging design. See the summary in Table 5.

Table 5. A summary of participants' feedback regarding knowledge communication through packaging.

\begin{tabular}{|c|c|c|}
\hline Proposals for Action & Evaluation from the Consumer Side & Evaluation from the Industry Side \\
\hline $\begin{array}{l}\text { Communicate knowledge } \\
\text { through packaging }\end{array}$ & $\begin{array}{l}\text { Packaging designed to encourage } \\
\text { people to evaluate food with } \\
\text { different senses. } \\
\text { Include tips for sensory assessments. } \\
\text { Written descriptions of sensory } \\
\text { attributes are insufficient. } \\
\text { Images that show a comparison } \\
\text { between edible and spoiled products. } \\
\text { Detailed information about the } \\
\text { ingredients that can go bad. }\end{array}$ & $\begin{array}{l}\text { Avoid touching upon the legal grey area. } \\
\text { Encourage consumers to trust } \\
\text { their senses. } \\
\text { Include information on how to better } \\
\text { use food items in its different shelf life } \\
\text { periods (e.g., recipes). } \\
\text { Prioritizing the mandatory labels due to } \\
\text { the space limit. }\end{array}$ \\
\hline
\end{tabular}

In the consumer workshop, participants indicated that the packaging can be designed to encourage people to use their senses-for example, G5 stated: "Packaging that encourages people to smell, squeeze and 
look at it, like use some kind of design, like put your nose here and smell instead of checking the date, or a transparent box or square on the package". They also expressed the need for sensory assessment knowledge, skills and criteria of food in different stages of its shelf life. In order to meet this particular need, participants proposed several ways to better illustrate the sensory features of food and pointed out the possibility of using these sensory illustrations to replace the "Best before" date. For example, G6 stated: "The best before date can be a description, like does it smell or taste like this, then it is good", G5 stated: "Remove the labels totally and put a picture instead, like this is fresh food, and this is how it would look like when it is gone bad".

However, industry participants pointed out that it is actually very problematic for them to present product sensory attributes on packaging. The possibility of legal conflicts is one of the problems that food manufacturers were concerned about. For example, I1 stated "I don't think you should encourage people to use their own judgments, because as soon as somebody gets it wrong, then I would blame the manufacturer if they become unaware", I4 stated "They [food manufacturers] don't want anything on here [product packaging] that they cannot legally do or is not going to help themselves." This concern was further supported by one of the comments from consumer participants, that the written descriptions of food sensory attributes on packaging might perhaps lead to confusions- "The written description is not that easy to show how it should smell like or feel like, like it should be spongy but not too spongy, and that doesn't help me at all" (G4).

Another concern from food industry participants was around packaging space. Food manufacturers are constantly prioritizing the spaces on packaging. The mandatory labels required by local food regulations and brand identity information are prioritized, while other supportive information such as differences between the "Best before" date and "Use by" date, sensory attributes, food waste and safety issues are usually cut off from packaging- "We are getting really wordy aren't $w e^{\prime \prime}(\mathrm{I} 2)$.

\subsection{Incorporate Technological Innovations}

Both consumer and industry practitioners proposed ideas of using smart labels and QR codes to better communicate labeling information on packaging. See a summary of ideas in Table 6 .

Table 6. A summary of participants' feedback regarding technological innovations.

\begin{tabular}{|c|c|c|}
\hline Proposals for Action & $\begin{array}{l}\text { Evaluation from the } \\
\text { Consumer Side }\end{array}$ & Evaluation from the Industry Side \\
\hline \multirow[t]{2}{*}{ Smart label/ real-time indicators } & \multirow{2}{*}{$\begin{array}{l}\text { Perceived as useful especially on } \\
\text { products that may cause food } \\
\text { safety risks (e.g., meat) and } \\
\text { products after opening. } \\
\text { Use color differences to indicate } \\
\text { the conditions of food. }\end{array}$} & $\begin{array}{l}\text { Advantages: } \\
\text { Avoid confusions between the "Best before" date and " } \\
\text { Use by" date; } \\
\text { Help to detect food status (e.g., temperature abuse) through } \\
\text { the supply chain and in the household; } \\
\text { Assign responsibility to consumers. }\end{array}$ \\
\hline & & $\begin{array}{l}\text { Drawbacks: } \\
\text { Different smart label standards can create more confusion } \\
\text { to consumers; } \\
\text { Add complexity to packaging recyclability; } \\
\text { Lack of economic incentives; } \\
\text { Take controls away from food manufacturers and retailers. }\end{array}$ \\
\hline \multirow[t]{2}{*}{$\begin{array}{l}\text { QR codes and consumer } \\
\text { mobile devices }\end{array}$} & \multirow[t]{2}{*}{$\begin{array}{l}\text { Simple technological solution. } \\
\text { Avoid disrupting the existing food } \\
\text { consumption activity routines. }\end{array}$} & $\begin{array}{l}\text { Advantages: } \\
\text { Simple and inexpensive solutions; } \\
\text { Save room on packaging; } \\
\text { A window for consumer interaction with product and brand; } \\
\text { Tailored communication of a variety of information to } \\
\text { consumers (e.g., shelf life, storage methods, environmental } \\
\text { impacts, recipes, production). }\end{array}$ \\
\hline & & $\begin{array}{l}\text { Drawbacks: } \\
\text { Effects vary across different socio-demographical groups and } \\
\text { socio-cultural background. }\end{array}$ \\
\hline
\end{tabular}

Smart labels were perceived as helpful by the consumer participants, especially on fresh produce that may cause food safety issues-"I would like that if it was like a meat package, like a little sticker went red 
if the food is not good. In your fridge, you can see that if it starts to say that, you should eat this soon" (G1). Similar to this point of view, smart labels were regarded by industry practitioners as a shortcut that can help consumers avoid confusions over the meaning of the "Best before" and "Use by" dates, as stated by I4: "Imagine buying a packet of mushrooms that has a little smart label on it with a green dot that stays Green, the consumer knows so, they know that rather than having a used by date."

However, the industry participants pointed out that smart labels might bring issues related to packaging recyclability_ "that might affect the recyclability of the package if it's got all these detectors in it" (I1). In this case, consumers need to be informed about how to recycle this type of packaging and form new behavior routines, which may add another layer to the complexity. The costs and consumers' willingness-to-pay is another concern that makes industry participants reluctant to implement smart labels-"we are squished by the real barrier of what consumers are prepared to pay" (I2), "I think it's too complex and the value of the product doesn't warrant it" (I1). As a result, the incentives behind the industry implementation of smart labels, according to I4, "might not actually be driven by packaging and it might not be driven by food waste. It might actually be driven by traceability and export regulation."

Communicating shelf life and storage information through QR codes and mobile devices was perceived positively by both consumer and industry participants. Industry participants regarded on-pack QR codes as a cost-effective way to save space on the packaging. They also considered it as a window of opportunity for consumers to further interact with the product and brand. And this communication was not limited to shelf life and food waste issues, as I3 stated: "It goes way beyond food waste, it goes for almost any kind of information you want to convey to your consumers". Messages such as the differences between the "Best before" and "Use by" dates, detailed storage guidance, productions, brand identity, recipe recommendations and environmental impacts of food waste, were pointed out by industry participants as the information that they would like to communicate to consumers through on-pack QR codes. This can also make it easier for the industry to update information constantly with little cost, compared with changing or adding information on packaging-for example, "you change within your IT department" (I3), "add or delete pieces of information from that webpage which the consumer can access. You can do it in real-time" (I5).

However, consumer participants also expressed their concern of being overwhelmed by the excessive use of mobile technology-for example, G4 stated: "I don't want to get notifications from the phone saying that your pasta sauce is turning bad. I understand the idea, but to me, this should be done so much simpler than that" (G4). Additionally, the QR codes usage rates may vary across different socio-demographical groups and socio-cultural background-for example, "I think it is a generational matter, it will move through as the millennials move on and take over the world" (I4), "QR codes haven't really taken off here in Australia. So big in China and other markets" (I2).

\section{Discussion}

To summarize the findings, in this paper, we have identified 12 tensions that consumers encounter in their food consumption activities in relation to date labeling and food waste issues. These tensions were categorized into four groups according to an activity theoretical lens: (a) consumers' lack of knowledge and proper usage of date and storage labeling, (b) variation in the effects of sensory assessment, (c) consumers' lack of internal embodied knowledge and experience when using sensory assessment in conjunction with labels and (d) ambiguous date labeling indication and a lack of standardization. Furthermore, based on the AT-based conceptual model we developed in the study, 16 proposals for action were consolidated into four groups: (a) improve date and storage information presentation on packaging, (b) improve labeling and sensory assessment knowledge communication through packaging, (c) a consumer education campaign and (d) incorporate technological innovations. Although the study is explorative, the findings from the literature review, consumer workshops and industry interviews are concrete to inform both theoretical contributions and practical design implications for design researchers and practitioners to intervene in the interaction between consumers and date labeling. 


\subsection{Theoretical Contributions}

Conceptual models that aim to address packaging and the consumer food waste problem have also been proposed by other studies. For example, with the goal of analyzing the impact that the level of understanding of date marking has on consumer food waste behavior, Toma and Thompson [8] proposed a model which indicates that consumer labeling-related food waste behavior can be influenced by three major factors: (1) socio-demographic of consumers, (2) perceptions regarding the need for clearer information about date labeling and frequency regarding checking date labels and (3) understanding of the labels. By focusing on consumer confusion over date labels, Hall-Phillips and Shah [15] presented a conceptual framework explicating how such confusion can influence the consumers' purchasing behavior regarding perishable grocery products. Based on the model, the difficulty in understanding and reading the labels were identified as two particular challenges regarding label information presentation. Based on a literature review and expert interviews, Aschemann-Witzel et al. [19] developed a conceptual model that illustrates the factors that influence consumer-related food waste. In their model, date labeling and consumer sensory assessment were listed as one of the major factors that influence consumer food waste behavior both before and after purchasing food items. Other factors identified in their model include socio-demographics, psycho-graphics, social influence and macro-environmental factors [19].

Compared with the above models, the novelty of this conceptual model lies in its particular lens on the consumer food edibility assessment system and the explicit focus on informing potential date labeling design suggestions (as illustrated in Figure 7). First, the findings of this study suggest that labeling-related food waste issues cannot be simply ascribed to one single factor such as the confusion over the meanings of the "Best before" date and "Use by" date or the socio-demographical background. Rather, the causes of the issue are inter-related and embedded in consumers' everyday food consumption actions. Identifying relevant factors thus requires researchers to draw a clear boundary and proper scope of the analysis. The conceptual model proposed in this study takes consumer food edibility assessment activity as the unit of analysis, which comprises elements such as sensory knowledge and skills, industry practitioners' intentions and practices. We argue that it not only provides detailed insights about specific on-pack labeling information design, but also can enable design practitioners to consider how to design the consumer-label interaction so that it can influence the larger consumer food edibility assessment system.

Furthermore, we suggest that the identified tensions are unlikely to be completely addressed without the incorporation of multiple proposals for action in multiple design interventions. The proposals for action are more effective when used in combination; for example, the confusion over the meanings of label terminology is more likely to be addressed by considering multiple interventions such as better labeling uniformity, consumer-friendly information display, better knowledge communication through packaging, a consumer education campaign and technological innovations.

\subsection{Design Implications}

Although many existing studies have proposed design interventions aiming at reducing consumer household food waste, practical design implications and solutions related to how to address labeling-related waste, or in a broader sense packaging-related waste, is currently lacking [2]. It is worth mentioning that based on the findings of the paper, we do not intend to make claims to advocate or oppose the use of a certain type of labeling design intervention. Rather, we focus on summarizing the potential design opportunities and challenges that emerged from the findings. Three major design implications can be derived from the findings.

First, we argue that instead of solely focusing on the standardization of label terminologies, efforts also need to be made to explore how date and storage information can be better presented to support consumers' correct understanding. Relevant labeling design guidance has already been proposed by governmental sectors and food waste research organizations. For example, the European Commission's Infographic Guidance on Date Marking aims to help consumers better understand the 
differences between the "Best before" and "Use by" dates [82,83]. For food manufacturers, guidelines such as the ReFED's Date Labeling Standardization Tool [29] and WRAP's Food Date Labeling and Storage Advice [30] were developed to help the industry practitioners determine which label to use for different products. However, none of the design guidelines mentioned above has provided food manufacturers and packaging designers with an explicit visual design language of where and how to present the information. We suggest that packaging designers can not only include descriptive explanations of the "Best before" and "Use by" dates on packaging, but also explore different graphic illustrations of product shelf life and the corresponding storage methods with consumers in different demographic groups. The consideration behind this design implication is to provide consumers with an easy way to visually spot and use date and storage labels on packaging.

Date labeling enables consumers to compare the current date with the date stated on the packaging. This comparison is quantifiable; it is either before, on, or past the date. However, the sensory perceptions that consumers commonly use are vision, smell and taste, which are difficult to directly measure since the criteria of what is good and bad are highly subjective and vary across each individual [68]. This feature leads to the discussion of the second design implication, which revolves around the challenge of communicating embodied sensory knowledge to consumers through packaging design. According to Hall-Phillips and Shah [19], consumer food-handling education is a task which policymakers, food manufacturers and retailers should take especially at the food purchase end. This is in line with our findings, which also suggest consumer education campaigns and knowledge communication on packaging (as illustrated in Figure 7) are the two most common ways to communicate sensory assessment-related knowledge and skills to consumers. However, due to a variety of concerns particularly about potential legal issues and business revenues involved in date labeling and packaging design, two fundamental questions have not been fully investigated both in the existing literature and industry practices: (1) What is the proper sensory knowledge information for consumers so that they would not be confused? and (2) How are consumers supposed to use their sensory knowledge in conjunction with labels for assessing different food products? To explore the specific questions mentioned above, we suggest that packaging researchers and designers begin with compressing the embodied sensory knowledge guidance into marks or codes on packaging, so that it allows consumers to retrieve tailored product sensory assessment information through mobile devices whenever consumers interact with the food items.

Third, compared with the first two design implications, which are focused on improving labeling content and display, technology innovations such as smart labels and digital interventions are more connected to the means and forms of communication. In a broader topic of consumer food waste, technology innovations have always been regarded as the key tools for changing consumer behavior and reduce food waste $[2,3,84]$. However, in terms of the specific date labeling topic, based on our findings, we argue that there might be a significant difference between consumers' perceptions and food industry practitioners' concerns regarding incorporating technological innovations in order to address food waste problems. Industry practitioners are particularly concerned about the potential benefits and impacts that technological solutions would bring to their costs and already-established food distribution system (e.g., food supply, retail and packaging recycling chain). For consumers, the challenge lies in whether technology solutions can fundamentally tackle all the identified tensions within the consumers' food edibility assessment system, and will the solutions trigger new problems associated with food waste and food safety. For instance, as different types of smart labels may apply different color indication mechanisms to show product conditions, consumers may need to check and learn the color instruction of the smart labels stated on each packaging, which could add another layer of complexity. This insight is in line with the study conducted by Kumar et al. [85], where they point out that readability, accuracy, nonuniform standards, cost, recycling issues, privacy and security concerns are the challenges that smart label application faces. In the long term, smart labels may still need to face a similar standardization and uniformity issue as what has been identified in the "Best before" and "Use by" dating system. Therefore, for design practitioners, we argue that technological 
innovations such as smart labels, QR codes and household food management applications can be used as mediating tools that assist consumers in making more informed food disposal decisions in their food edibility assessment activities. However, this does not necessarily mean that these technological innovations can completely replace the current on-pack date and storage labeling. Rather, design practitioners need to find a window to incorporate these technological innovations with conventional packaging design.

\subsection{Limitations of the Study}

As for the present study, we acknowledge that it has a few limitations. As the study specifically focuses on the interaction between consumers and date labeling in the household environment, we excluded the influences that date and storage labeling have in the food purchasing stage. On-pack date and storage information attributes can also largely affect consumers' willingness-to-pay for the food in the market [86]; however this goes beyond the scope of this paper. We also acknowledge the lack of in-depth discussion of labeling-related food safety issues that consumers face, particularly as it relates to the interplay between consumer sensory judgment and the use of date labels. This lack of food safety discussion is due to the primary focus of investigating labeling-related food waste issues in the present study. Acknowledging this limitation can help us to better structure the date labeling and food waste research focuses in future works. In the consumer workshops, a sample size of 10 participants might be considered small. The participants were recruited by the authors' professional networks and the demographic background such as gender, age, and profession were not taken into consideration in the recruitment process, which may lead to the potential risk of bias. On the other hand, this type of consumer workshop in the early stage of the design exploration allowed us to develop richer and descriptive knowledge about the labeling problem. Furthermore, the industry interviews were conducted with food industry practitioners in Australia, while the consumer workshops took place in Sweden. The different socio-cultural contexts may have brought some influences to data accuracy, but on the other hand, it also provided the opportunity for us to discuss date and storage labeling in a more international setting.

\section{Conclusions and Future Works}

With the overarching goal to reduce packaging-related food waste, in the present study we specifically focused on exploring the opportunities for design to intervene in the interaction between consumers and date labeling. The key findings from the literature review and the co-creation sessions (consumer workshops and the industry interviews) indicate the importance of investigating the role that date and storage labeling play from a system level. From a packaging design perspective, we argue that solely focusing on addressing the question of how people perceive date labeling is likely to be insufficient. In order to develop design opportunities that have larger and more fundamental impacts, tensions embedded in the consumer food edibility assessment activity system such as how consumers use their sensory perceptions in combination with labels, their specific food consumption goals associated with food waste and safety issues and the practical labeling concerns that the food and packaging industry holds need to be taken into analysis.

Furthermore, this study works as the first step in translating existing knowledge into practical design interventions that help consumers to reduce labeling-related household food waste. We suggest that the conceptual model developed in this study can be used not only as a framework that guides researchers to identify and analyze labeling-related food waste problems that each individual consumer encounters, but also as a guideline that assists packaging design practitioners in exploring potential design opportunities to solve the problem from a system perspective. And we recommend that in order to support consumers in reducing labeling-related food waste, multiple design interventions need to be implemented and evaluated to find out which interventions can efficiently solve the tensions identified in different case scenarios. 
We believe that improving the small piece of date and storage information on packaging can make big differences in reducing consumer food waste in the future. For future research, our next step is to evaluate the design interventions identified in this study in consumer real household contexts. Meanwhile, we also aim to reach more food industry practitioners to gather their feedback about potential design interventions.

Author Contributions: The major part of the manuscript was written by W.C., while H.W., K.V., R.W. and W.G. were consulted for reviewing and editing. H.W. and K.V. were the supervisors of this research project; they guided the literature review and the empirical data collection and analysis. H.W. and K.V. also provided their professional research networks for recruiting packaging and food industry participants. R.W. and W.G. are the supervisors of W.C.'s PhD study; they contributed to the paper by providing research ideas and guiding the development of the theoretical lens and the overall research methodology; All authors have read and agreed to the published version of the manuscript.

Funding: This research received no external funding.

Acknowledgments: The corresponding author is grateful for the IAPRI for granting the exchange scholarship (sponsored by PepsiCo) to the corresponding author, the warm support from the Australian Institute of Packaging (AIP) and RMIT Universit, and the scholarship support from the China Scholarship Council and Machine Design Division, Linköping University. We gratefully acknowledge the time and contributions of all the study participants and reviewers.

Conflicts of Interest: The authors declare no conflict of interest. 


\section{Appendix A}

Table A1. Detailed literature review results.

\begin{tabular}{|c|c|c|c|c|c|c|c|}
\hline Study & Perspective & $\begin{array}{l}\text { Aim and } \\
\text { Research Question }\end{array}$ & $\begin{array}{l}\text { Research Methodology: } \\
\text { Qualitative or } \\
\text { Quantitative-Based }\end{array}$ & $\begin{array}{l}\text { Sample Size } \\
\text { and Region }\end{array}$ & Product Category & $\begin{array}{l}\text { Key Results Regarding the Role } \\
\text { that Date and Storage } \\
\text { Labeling Plays }\end{array}$ & Proposed Suggestions and Actions \\
\hline Thompson et al., 2018 [57] & $\begin{array}{l}\text { Consumer food } \\
\text { waste }\end{array}$ & $\begin{array}{l}\text { The relationship between } \\
\text { product type, date type, } \\
\text { reduced labels and } \\
\text { willingness to consume } \\
\text { dairy products in relation to } \\
\text { the both the "Best before" } \\
\text { and "Use by" dates }\end{array}$ & $\begin{array}{l}\text { Online survey, } \\
\text { statistical analysis }\end{array}$ & $\begin{array}{l}548 \text { Scottish } \\
\text { consumers }\end{array}$ & Dairy products & $\begin{array}{l}\text { The effect on food waste reduction of } \\
\text { moving more dairy products to the } \\
\text { "Best before" dates is likely } \\
\text { to be small. }\end{array}$ & $\begin{array}{l}\text { Communication will need to go beyond just } \\
\text { providing knowledge information that it is } \\
\text { safe to eat products beyond the "Best before" } \\
\text { date. Addressing consumer risk perceptions } \\
\text { and label trust issues is also of the } \\
\text { same importance. }\end{array}$ \\
\hline Wilson et al., 2018 [56] & $\begin{array}{l}\text { Consumer } \\
\text { interpretations of } \\
\text { labels and } \\
\text { food waste }\end{array}$ & $\begin{array}{l}\text { Consumers' perceptions of } \\
\text { "Best by" and "Use by" } \\
\text { between different food } \\
\text { items across } \\
\text { different attributes }\end{array}$ & $\begin{array}{l}\text { Experimental auctions } \\
\text { and survey, } \\
\text { statistical analysis }\end{array}$ & $\begin{array}{l}206 \text { participants in } \\
\text { the US }\end{array}$ & $\begin{array}{l}\text { Spaghetti } \\
\text { sauce and deli } \\
\text { meat }\end{array}$ & $\begin{array}{l}\text { Consumers seem to associate the } \\
\text { "Best by" dates less with safety than } \\
\text { taste or quality. However, some } \\
\text { consumers may still waste edible } \\
\text { products with the "Best by" dates as } \\
\text { the product approaches the date, } \\
\text { even for shelf-stable products. }\end{array}$ & $\begin{array}{l}\text { Information campaigns will be necessary to } \\
\text { help consumers understand and use } \\
\text { date labels. }\end{array}$ \\
\hline Roe et al., 2018 [58] & $\begin{array}{l}\text { Consumer food } \\
\text { waste }\end{array}$ & $\begin{array}{l}\text { Understanding how } \\
\text { consumers react to the } \\
\text { presence and absence of } \\
\text { date labels on milk }\end{array}$ & $\begin{array}{l}\text { Laboratory experiment, } \\
\text { statistical analysis }\end{array}$ & $\begin{array}{l}88 \text { participants in } \\
\text { the US }\end{array}$ & Milk & $\begin{array}{l}\text { Simply removing date labels } \\
\text { may not achieve large reductions in } \\
\text { milk discards, as the absence of a } \\
\text { date label appears to induce } \\
\text { significantly more discards of in-date } \\
\text { milk. }\end{array}$ & $\begin{array}{l}\text { Empower consumers to better rely upon their } \\
\text { senses when evaluating products like milk by } \\
\text { introducing innovative date labeling or } \\
\text { enhanced education about date labels. }\end{array}$ \\
\hline Toma et al., 2017 [8] & $\begin{array}{l}\text { Consumer food } \\
\text { waste }\end{array}$ & $\begin{array}{l}\text { Analyze the impact that the } \\
\text { level of understanding of } \\
\text { date labeling (among other } \\
\text { influences) has on the food } \\
\text { waste behavior } \\
\text { of consumers }\end{array}$ & $\begin{array}{l}\text { Data extracted from the } \\
\text { Eurobarometer Survey, } \\
\text { statistical analysis }\end{array}$ & $\begin{array}{l}\text { Citizens in the } 28 \\
\text { member states of } \\
\text { the European } \\
\text { Union with an } \\
\text { average sample } \\
\text { size of } 950\end{array}$ & $\begin{array}{l}\text { General food } \\
\text { product }\end{array}$ & $\begin{array}{l}\text { Socio-demographics, date label } \\
\text { understanding, need for clearer date } \\
\text { labeling information and frequency } \\
\text { of date label checking have } \\
\text { significant effects on reducing } \\
\text { food waste. }\end{array}$ & $\begin{array}{l}\text { Need for clearer information about date } \\
\text { marking as consumers have become less } \\
\text { knowledgeable of the characteristics } \\
\text { associated with food safety and quality and } \\
\text { rely increasingly on food label instructions. }\end{array}$ \\
\hline $\begin{array}{l}\text { Hall-Phillips and Shah, } \\
2017 \text { [19] }\end{array}$ & $\begin{array}{l}\text { Consumer } \\
\text { interpretations of } \\
\text { labels }\end{array}$ & $\begin{array}{l}\text { The role of unclarity, } \\
\text { confusion surrounding } \\
\text { expiration dates on the } \\
\text { consumers' path to } \\
\text { purchasing } \\
\text { grocery products }\end{array}$ & $\begin{array}{l}\text { Semi-structured interview, } \\
\text { thematic analysis }\end{array}$ & $\begin{array}{l}19 \text { participants in } \\
\text { the US }\end{array}$ & Grocery products & $\begin{array}{l}\text { Consumer confusion over expiration } \\
\text { dates is caused by not only their lack } \\
\text { of understanding of date labels, but } \\
\text { also the consistency and the various } \\
\text { formats and displays of labels. }\end{array}$ & $\begin{array}{l}\text { 1) Consumers need education on food safety } \\
\text { information and freshness characteristics that } \\
\text { will enable proper handling and safe food } \\
\text { storage at the consumers' end; } \\
\text { 2) Manufacturers can provide better and } \\
\text { clearer label formats across brands and/or } \\
\text { products. Including more consumer-friendly } \\
\text { information on food packages, such as } \\
\text { consistent expiration date labels that can } \\
\text { provide consumers with additional product } \\
\text { freshness and/or quality information. }\end{array}$ \\
\hline Wilson et al., 2017 [55] & $\begin{array}{l}\text { Consumer food } \\
\text { waste }\end{array}$ & $\begin{array}{l}\text { How date labels influence } \\
\text { their willingness-to-waste } \\
\text { (WTW) }\end{array}$ & $\begin{array}{l}\text { Laboratory experiment, } \\
\text { statistical analysis }\end{array}$ & $\begin{array}{l}200 \text { participants in } \\
\text { the US }\end{array}$ & $\begin{array}{l}\text { Ready-to-eat } \\
\text { cereal, salad } \\
\text { greens and yogurt }\end{array}$ & $\begin{array}{l}\text { Consumers' WTW is highest in the } \\
\text { “Use by" date which suggests food } \\
\text { safety, and lower in labels which } \\
\text { suggest food quality. }\end{array}$ & Did not indicate explicit suggestions. \\
\hline
\end{tabular}


Table A1. Cont.

\begin{tabular}{|c|c|c|c|c|c|c|c|}
\hline Study & Perspective & $\begin{array}{l}\text { Aim and } \\
\text { Research Question }\end{array}$ & $\begin{array}{l}\text { Research Methodology: } \\
\text { Qualitative or } \\
\text { Quantitative-Based }\end{array}$ & $\begin{array}{l}\text { Sample Size } \\
\text { and Region }\end{array}$ & Product Category & $\begin{array}{l}\text { Key Results Regarding the Role } \\
\text { that Date and Storage } \\
\text { Labeling Plays }\end{array}$ & Proposed Suggestions and Actions \\
\hline $\begin{array}{l}\text { Van Boxstael et al., } \\
2014 \text { [68] }\end{array}$ & $\begin{array}{l}\text { Consumer } \\
\text { interpretations of } \\
\text { labels and food } \\
\text { edibility } \\
\text { assessment }\end{array}$ & $\begin{array}{l}\text { Belgian consumers' } \\
\text { understanding and attitude } \\
\text { towards shelf life labels } \\
\text { and dates }\end{array}$ & $\begin{array}{l}\text { Online survey, } \\
\text { statistical analysis }\end{array}$ & $\begin{array}{l}907 \text { Belgian } \\
\text { consumers }\end{array}$ & $\begin{array}{l}\text { General food } \\
\text { product }\end{array}$ & $\begin{array}{l}\text { 1) Most of the consumers interpret } \\
\text { shelf life labels and dates with } \\
\text { variation depending upon the type of } \\
\text { food product under consideration. } \\
\text { 2) Judging edibility of food products } \\
\text { at home occurs mainly by a } \\
\text { combination of checking visually and } \\
\text { smelling, followed by looking at the } \\
\text { shelf life date or tasting. }\end{array}$ & $\begin{array}{l}\text { An increase in the understanding of date } \\
\text { labels by consumers is needed. }\end{array}$ \\
\hline $\begin{array}{l}\text { Hebrok and Heidenstrøm, } \\
2019 \text { [14] }\end{array}$ & $\begin{array}{l}\text { Consumer food } \\
\text { waste }\end{array}$ & $\begin{array}{l}\text { Identify decisive moments } \\
\text { and contexts for food waste } \\
\text { prevention and discuss } \\
\text { examples of measures that } \\
\text { could be further explored }\end{array}$ & $\begin{array}{l}\text { Fieldwork, qualitative } \\
\text { coding }\end{array}$ & $\begin{array}{l}26 \text { households in } \\
\text { Norway }\end{array}$ & $\begin{array}{l}\text { General food } \\
\text { product }\end{array}$ & $\begin{array}{l}\text { Consumer food assessment is in a } \\
\text { dynamic negotiation process between } \\
\text { institutionalized knowledge of date } \\
\text { labels and embodied knowledge of } \\
\text { food sensory evaluations with past } \\
\text { experience. }\end{array}$ & $\begin{array}{l}\text { 1) Use alternative ways to indicate shelf life } \\
\text { and support consumers' own assessments and } \\
\text { avoid insecurities; } \\
\text { 2) Knowledge and awarenesscampaigns on the } \\
\text { meaning of date labeling are insufficient in } \\
\text { achieving food waste reduction, } \\
\text { communicating knowledge at the decisive } \\
\text { food-handling moments is more effective. }\end{array}$ \\
\hline Dickinson et al., 2014 [61] & $\begin{array}{l}\text { Consumer food } \\
\text { safety }\end{array}$ & $\begin{array}{l}\text { To examine what actually } \\
\text { happens in domestic } \\
\text { kitchens in older people's } \\
\text { homes to assess whether } \\
\text { and how food safety issues } \\
\text { are caused }\end{array}$ & $\begin{array}{l}\text { Ethnographic approach, } \\
\text { qualitative analysis }\end{array}$ & $\begin{array}{l}10 \text { households } \\
\text { with older people } \\
\text { (aged 60+) in the } \\
\text { UK }\end{array}$ & $\begin{array}{l}\text { General food } \\
\text { product }\end{array}$ & $\begin{array}{l}\text { The lack of trust in the food supply, } \\
\text { use of food labeling, sensory logics } \\
\text { and food waste concerns were } \\
\text { potential factors that influence risk of } \\
\text { foodborne illness in older people. }\end{array}$ & Did not indicate explicit suggestions. \\
\hline Lenhart et al., 2008 [62] & $\begin{array}{l}\text { Consumer } \\
\text { interpretations of } \\
\text { labels and } \\
\text { consumer food } \\
\text { safety }\end{array}$ & $\begin{array}{l}\text { To better understand } \\
\text { consumers' opinions about } \\
\text { various date and food safety } \\
\text { labeling statements among } \\
\text { the selected high-risk } \\
\text { population groups }\end{array}$ & $\begin{array}{l}\text { Focus group discussion, } \\
\text { qualitative coding }\end{array}$ & $\begin{array}{l}85 \text { senior aged } \\
\text { women and } \\
\text { women of } \\
\text { childbearing age } \\
\text { in the US }\end{array}$ & $\begin{array}{l}\text { Refrigerated } \\
\text { ready-to-eat (RTE) } \\
\text { meat and poultry } \\
\text { products }\end{array}$ & $\begin{array}{l}\text { 1) From a food safety perspective, } \\
\text { "Use by" statements were considered } \\
\text { clearer and more helpful than "Sell } \\
\text { by" or "Best if used by" labels by the } \\
\text { participants; } \\
\text { 2) Labels giving consumers } \\
\text { instructions on how long they could } \\
\text { keep RTE products and when to } \\
\text { discard them after opening were } \\
\text { considered helpful. }\end{array}$ & $\begin{array}{l}\text { 1) A strong need for consumer education on } \\
\text { guidelines for safe storage of opened packages } \\
\text { of RTE meat and poultry products; } \\
\text { 2) Participants wanted to receive the } \\
\text { information through point-of-purchase } \\
\text { pamphlets located near the deli case and } \\
\text { through mass media venues; } \\
\text { 3) Manufacturers are encouraged to provide } \\
\text { more complete information on the safe storage } \\
\text { and use of RTE meat and poultry products on } \\
\text { package labels. }\end{array}$ \\
\hline Samotyja, 2015 [69] & $\begin{array}{l}\text { Consumer food } \\
\text { edibility } \\
\text { assessment }\end{array}$ & $\begin{array}{l}\text { To assess how shelf-life } \\
\text { labeling affects the sensory } \\
\text { acceptability of potato } \\
\text { snacks }\end{array}$ & $\begin{array}{l}\text { Laboratory testing, } \\
\text { chemical analyses, } \\
\text { statistical analysis }\end{array}$ & $\begin{array}{l}110 \text { students in } \\
\text { Poland }\end{array}$ & Potato snacks & $\begin{array}{l}\text { Consumers are more cautious when } \\
\text { they have no dating information or } \\
\text { they notice deteriorative changes; } \\
\text { they are willing to trust their own } \\
\text { senses more than the labeling. }\end{array}$ & $\begin{array}{l}\text { Date legislation is necessary but it may be } \\
\text { insufficient without consumer education. }\end{array}$ \\
\hline Abeliotis et al., 2016 [23] & $\begin{array}{l}\text { Consumer } \\
\text { interpretations of } \\
\text { labels and } \\
\text { consumer food } \\
\text { waste }\end{array}$ & $\begin{array}{l}\text { To identify the extent of } \\
\text { engagement in nine } \\
\text { different everyday } \\
\text { consumer behaviors } \\
\text { suggested by WRAP and of } \\
\text { the effect of the Greek } \\
\text { households' characteristics } \\
\text { towards food } \\
\text { waste prevention }\end{array}$ & $\begin{array}{l}\text { Questionnaire, statistical } \\
\text { analysis }\end{array}$ & $\begin{array}{l}231 \text { shoppers in } \\
\text { Greece }\end{array}$ & $\begin{array}{l}\text { General food } \\
\text { product }\end{array}$ & $\begin{array}{l}\text { The reported consumer knowledge of } \\
\text { food date labels indicates that there is } \\
\text { plenty of room for education of the } \\
\text { consumers regarding the proper } \\
\text { meaning of the two food date labels. }\end{array}$ & $\begin{array}{l}\text { The consumer knowledge on the "Expiration } \\
\text { date" and "Best used before" food labels } \\
\text { should be improved. }\end{array}$ \\
\hline
\end{tabular}


Table A1. Cont.

\begin{tabular}{|c|c|c|c|c|c|c|c|}
\hline Study & Perspective & $\begin{array}{l}\text { Aim and Research } \\
\text { Question }\end{array}$ & $\begin{array}{l}\text { Research Methodology: } \\
\text { Qualitative or } \\
\text { Quantitative-Based } \\
\end{array}$ & $\begin{array}{l}\text { Sample Size and } \\
\text { Region }\end{array}$ & Product Category & $\begin{array}{l}\text { Key Results Regarding the Role } \\
\text { that Date and Storage Labeling } \\
\text { Plays }\end{array}$ & Proposed Suggestions and Actions \\
\hline Daelman et al., 2013 [63] & $\begin{array}{l}\text { Consumer food } \\
\text { safety }\end{array}$ & $\begin{array}{l}\text { To assess the consumption } \\
\text { frequency, storage time, } \\
\text { reheating practices and } \\
\text { perception of and respect for } \\
\text { the product's "Use by" date }\end{array}$ & $\begin{array}{l}\text { Questionnaire, statistical } \\
\text { analysis }\end{array}$ & $\begin{array}{l}874 \text { respondents in } \\
\text { Belgium }\end{array}$ & $\begin{array}{l}\text { Refrigerated and } \\
\text { Processed Foods of } \\
\text { Extended } \\
\text { Durability } \\
\text { (REPFEDs) }\end{array}$ & $\begin{array}{l}\text { Only half of the consumers fully } \\
\text { respected the "Use by" date as } \\
\text { indicated on the packaging of } \\
\text { REPFED products. The majority of } \\
\text { the remaining consumers would } \\
\text { consume the product until three days } \\
\text { past the "Use by" date. }\end{array}$ & Did not indicate explicit suggestions. \\
\hline Yngfalk, 2016 [39] & $\begin{array}{l}\text { Consumer food } \\
\text { edibility } \\
\text { assessment and } \\
\text { food waste }\end{array}$ & $\begin{array}{l}\text { The potential that date } \\
\text { labeling holds for } \\
\text { constructing and shaping } \\
\text { consumers' food } \\
\text { consumption and disposal } \\
\text { behavior }\end{array}$ & $\begin{array}{l}\text { Interviews in the practice } \\
\text { of meals, qualitative } \\
\text { discourse analysis }\end{array}$ & $\begin{array}{l}\text { Did not present in } \\
\text { the paper }\end{array}$ & $\begin{array}{l}\text { General food } \\
\text { product }\end{array}$ & $\begin{array}{l}\text { Date labeling largely constrains the } \\
\text { ability of consumers to sense food by } \\
\text { imposing an externally generated } \\
\text { form of expert knowledge rather than } \\
\text { an embodied sensory knowledge, } \\
\text { thus is responsible for growing } \\
\text { food waste. }\end{array}$ & Did not indicate explicit suggestions. \\
\hline Wikström et al., 2014 [21] & $\begin{array}{l}\text { Consumer food } \\
\text { waste }\end{array}$ & $\begin{array}{l}\text { To highlight packaging } \\
\text { attributes that influence } \\
\text { food waste, and present a } \\
\text { method to illustrate how } \\
\text { food waste may be } \\
\text { integrated into future } \\
\text { packaging LCAs. }\end{array}$ & $\begin{array}{l}\text { Life cycle assessment } \\
\text { (LCA) }\end{array}$ & $\begin{array}{l}6 \text { packaging } \\
\text { formats }\end{array}$ & Rice and yogurt & $\begin{array}{l}\text { Consumers are interested in } \\
\text { packaging that gives clear messages } \\
\text { about shelf life and storage method. } \\
\text { However, consumers are not using } \\
\text { the actual information that is already } \\
\text { on the packaging. }\end{array}$ & $\begin{array}{l}\text { 1) Packaging has the advantage of providing } \\
\text { specific information on the particular item just } \\
\text { when it is needed. For example, information } \\
\text { about the dating system, if and when the food } \\
\text { item could be unhealthy, and how the } \\
\text { consumer could judge the quality of the } \\
\text { food item. } \\
\text { 2) Use smart labels to indicate when the food } \\
\text { item is safe/of high quality. }\end{array}$ \\
\hline $\begin{array}{l}\text { Aschemann-Witzel et al., } \\
2016 \text { [60] }\end{array}$ & $\begin{array}{l}\text { Food marketer and } \\
\text { retailer in reducing } \\
\text { consumer food } \\
\text { waste }\end{array}$ & $\begin{array}{l}\text { To identify causes and } \\
\text { potential for actions against } \\
\text { consumer food waste from } \\
\text { the perspective of food } \\
\text { marketing and retailers }\end{array}$ & $\begin{array}{l}\text { A literature review, } \\
\text { an expert interview study } \\
\text { and case study analysis }\end{array}$ & 11 experts & $\begin{array}{l}\text { General food } \\
\text { product }\end{array}$ & $\begin{array}{l}\text { 1) Food marketing and retailing } \\
\text { contribute to consumer-related food } \\
\text { waste via decisions on date labeling, } \\
\text { product shelf life and package design } \\
\text { elements that impact storage; } \\
\text { 2) Food marketing and retailer } \\
\text { communication on quality } \\
\text { characteristics may also have } \\
\text { heightened safety and health } \\
\text { concerns or freshness orientation } \\
\text { beyond consumers' factual need. }\end{array}$ & $\begin{array}{l}\text { Food marketers and retailers need to better } \\
\text { design on-pack date and storage information } \\
\text { to improve consumers' capabilities to handle } \\
\text { food and solve tradeoffs between food waste } \\
\text { avoidance and other food consumption goals. }\end{array}$ \\
\hline Ceuppens et al., 2016 [66] & $\begin{array}{l}\text { Food retailer in } \\
\text { consumer food } \\
\text { safety }\end{array}$ & $\begin{array}{l}\text { To investigate the use and } \\
\text { consistency in date labels } \\
\text { (i.e., "Use by" and "Best } \\
\text { before") and storage } \\
\text { instructions }\end{array}$ & $\begin{array}{l}\text { Snapshot of products, } \\
\text { stakeholder survey, lab } \\
\text { testing, statistical analysis } \\
\text { and qualitative analysis }\end{array}$ & $\begin{array}{l}4 \text { supermarket } \\
\text { chains in Belgium }\end{array}$ & $\begin{array}{l}\text { Pre-packed } \\
\text { refrigerated food } \\
\text { products }(\mathrm{n}=1477)\end{array}$ & $\begin{array}{l}\text { A mixed use of the "Use by" and } \\
\text { "Best before" dates and } \\
\text { recommended storage conditions } \\
\text { within a refrigerated food product } \\
\text { category confuses consumers and } \\
\text { thus leads to food waste and safety } \\
\text { issues. }\end{array}$ & $\begin{array}{l}\text { 1) To allocate to one food category one type of } \\
\text { date label, which would ensure clarity to the } \\
\text { producer/retailer and avoid confusion with } \\
\text { consumers on how to handle these food } \\
\text { products; } \\
\text { 2) To keep a balance between food safety and } \\
\text { waste concerns when setting date labels. }\end{array}$ \\
\hline Milne, 2012 [9] & $\begin{array}{l}\text { Date labeling } \\
\text { regulation }\end{array}$ & $\begin{array}{l}\text { How reforms to date } \\
\text { marking have occurred in } \\
\text { response to consumers' } \\
\text { shiffting concerns about } \\
\text { food quality, safety and } \\
\text { latterly waste }\end{array}$ & $\begin{array}{l}\text { A review of date labeling } \\
\text { regulations in history }\end{array}$ & UK & $\begin{array}{l}\text { General food } \\
\text { product }\end{array}$ & $\begin{array}{l}\text { Date labeling systems reflect societal } \\
\text { anxieties about the food system and } \\
\text { incorporate the changing role of } \\
\text { consumers-from concerned } \\
\text { housewives to neo-liberal agents of } \\
\text { food safety to environmentally } \\
\text { responsible actors. }\end{array}$ & Did not indicate explicit suggestions. \\
\hline
\end{tabular}


Table A1. Cont.

\begin{tabular}{|c|c|c|c|c|c|c|c|}
\hline Study & Perspective & $\begin{array}{l}\text { Aim and Research } \\
\text { Question }\end{array}$ & $\begin{array}{l}\text { Research Methodology: } \\
\text { Qualitative or } \\
\text { Quantitative-Based }\end{array}$ & $\begin{array}{l}\text { Sample Size } \\
\text { and Region }\end{array}$ & Product Category & $\begin{array}{l}\text { Key Results Regarding the Role } \\
\text { that Date and Storage } \\
\text { Labeling Plays }\end{array}$ & Proposed Suggestions and Actions \\
\hline Ransom, 2005 [67] & $\begin{array}{l}\text { Date labeling } \\
\text { regulation }\end{array}$ & $\begin{array}{l}\text { To provide scientific } \\
\text { evidence for establishing } \\
\text { Safety-Based Consume-By } \\
\text { Date Labels (BDDL) for } \\
\text { Refrigerated Ready-to-Eat } \\
\text { Foods }\end{array}$ & Scientific review & US & $\begin{array}{l}\text { Ready-to-Eat } \\
\text { (RTE) Food }\end{array}$ & $\begin{array}{l}\text { The use of appropriate safety-based } \\
\text { consume-by date labels could have a } \\
\text { beneficial public health impact for } \\
\text { reducing foodborne illness. }\end{array}$ & $\begin{array}{l}\text { The application of SBDL may need to be } \\
\text { combined with an effective educational } \\
\text { program for temperature control at the } \\
\text { consumer level to reach a positive impact on } \\
\text { public health. }\end{array}$ \\
\hline Newsome et al., 2014 [24] & $\begin{array}{l}\text { Date labeling } \\
\text { regulation }\end{array}$ & $\begin{array}{l}\text { A comprehensive review of } \\
\text { the issue of food product } \\
\text { date labeling }\end{array}$ & Literature review & $\begin{array}{l}\text { US and } \\
\text { international } \\
\text { framework }\end{array}$ & $\begin{array}{l}\text { General food } \\
\text { product }\end{array}$ & $\begin{array}{l}\text { The variation in date labeling terms } \\
\text { and uses contributes to substantial } \\
\text { misunderstandings by industry and } \\
\text { consumers and leads to significant } \\
\text { unnecessary food loss and waste and } \\
\text { potential food safety risk in regards } \\
\text { to food. }\end{array}$ & $\begin{array}{l}\text { 1) Collaborate to move towards uniformity in } \\
\text { date labeling and storage instructions; } \\
\text { 2) Apply consumer education solutions and } \\
\text { develop technologies at the household level to } \\
\text { help consumers understand date information. }\end{array}$ \\
\hline Corradini, 2018 [34] & $\begin{array}{l}\text { Consumer food } \\
\text { edibility } \\
\text { assessment }\end{array}$ & $\begin{array}{l}\text { To summarizes the } \\
\text { necessary steps to attain a } \\
\text { transition from open } \\
\text { labeling to real-time } \\
\text { shelf-life measurements }\end{array}$ & Literature review & $\begin{array}{l}\text { Did not explicitly } \\
\text { indicate }\end{array}$ & $\begin{array}{l}\text { General food } \\
\text { product }\end{array}$ & $\begin{array}{l}\text { The static date labels do not take into } \\
\text { consideration conditions that might } \\
\text { shorten a product's shelf life (such as } \\
\text { temperature abuse), } \\
\text { which can lead to problems } \\
\text { associated with food safety and } \\
\text { waste. }\end{array}$ & $\begin{array}{l}\text { Novel analytical tools to determine safety and } \\
\text { quality attributes with modern tracking } \\
\text { technologies and appropriate predictive tools } \\
\text { have the potential to provide accurate } \\
\text { estimations of the remaining shelf life of a food } \\
\text { product in real time. }\end{array}$ \\
\hline Williams et al., 2012 [22] & $\begin{array}{l}\text { Consumer food } \\
\text { waste }\end{array}$ & $\begin{array}{l}\text { To explore how and to what } \\
\text { extent packaging influences } \\
\text { the amount of food waste in } \\
\text { the household }\end{array}$ & $\begin{array}{l}\text { Diary method, } \\
\text { quantitative analysis }\end{array}$ & $\begin{array}{l}61 \text { households in } \\
\text { Sweden }\end{array}$ & $\begin{array}{l}\text { General food } \\
\text { product }\end{array}$ & $\begin{array}{l}\text { Food that passed the "Best before" } \\
\text { date plays a significant role in } \\
\text { packaging-related food waste. The } \\
\text { environmentally educated } \\
\text { households wasted less food due to } \\
\text { passed "Best before" dates. }\end{array}$ & $\begin{array}{l}\text { Packaging is a potential information carrier } \\
\text { that can be used to inform and explain how } \\
\text { the consumer can use the "Best before" date, } \\
\text { for example by explaining that it is safe to taste } \\
\text { the content and judge if it is good. }\end{array}$ \\
\hline Woolley et al., 2016 [33] & $\begin{array}{l}\text { Food } \\
\text { manufacturers and } \\
\text { retailers in } \\
\text { reducing } \\
\text { consumer food } \\
\text { waste }\end{array}$ & $\begin{array}{l}\text { How the prevention of food } \\
\text { waste can be facilitated by } \\
\text { using the concept of } \\
\text { industrial inventory } \\
\text { management in consumer } \\
\text { food items management }\end{array}$ & Survey, statistical analysis & $\begin{array}{l}10 \text { participants in } \\
\text { the UK }\end{array}$ & $\begin{array}{l}\text { High weight, cost, } \\
\text { environmental } \\
\text { impact products } \\
\text { (e.g., animal } \\
\text { products) }\end{array}$ & $\begin{array}{l}\text { By recording and transferring data } \\
\text { regarding product “Use by" dates to } \\
\text { consumers' mobile devices, it can } \\
\text { enable consumers to better monitor } \\
\text { food items and consume the product } \\
\text { before its expiry date is reached. }\end{array}$ & $\begin{array}{l}\text { Opportunities for the manufacturing industry } \\
\text { to assist consumers in reducing food waste by } \\
\text { developing tools prevalent in the industry for } \\
\text { the domestic environment. }\end{array}$ \\
\hline $\begin{array}{l}\text { Watson and Meah, } \\
2012 \text { [59] }\end{array}$ & $\begin{array}{l}\text { Consumer food } \\
\text { waste and food } \\
\text { safety }\end{array}$ & $\begin{array}{l}\text { Understand how } \\
\text { participants negotiate the } \\
\text { "Use by" dates and what } \\
\text { kinds of interventions } \\
\text { should be introduced to } \\
\text { reduce food waste }\end{array}$ & $\begin{array}{l}\text { Focus groups, life-history } \\
\text { interviews and } \\
\text { observations, qualitative } \\
\text { analysis }\end{array}$ & Did not present & $\begin{array}{l}\text { General food } \\
\text { products }\end{array}$ & $\begin{array}{l}\text { 1) Date labels tend to redistribute } \\
\text { responsibility away from consumers' } \\
\text { own sensory assessments; } \\
\text { 2) What pulls people away from } \\
\text { following the "Use by" date is the } \\
\text { tension between institutionalized } \\
\text { knowledge of date labels and } \\
\text { antipathy towards food waste. }\end{array}$ & $\begin{array}{l}\text { Information campaigns emphasizing issues of } \\
\text { environmental responsibility have limited } \\
\text { potential for reducing food waste. A different } \\
\text { focus for interventions is to enable people to } \\
\text { enact thriftiness. }\end{array}$ \\
\hline Labuza et al., 2008 [27] & $\begin{array}{l}\text { Consumer } \\
\text { interpretations of } \\
\text { labels and food } \\
\text { safety }\end{array}$ & $\begin{array}{l}\text { To better understand } \\
\text { consumers' perceptions } \\
\text { regarding the proper } \\
\text { handling and storage of } \\
\text { refrigerated foods }\end{array}$ & Survey, statistical analysis & $\begin{array}{l}101 \text { consumers in } \\
\text { the US }\end{array}$ & $\begin{array}{l}\text { Refrigerated foods } \\
\text { products }\end{array}$ & $\begin{array}{l}\text { 1) Consumer confusion regarding the } \\
\text { meaning of open dates continues; } \\
\text { 2) Many consumers in the study are } \\
\text { lacking in basic food safety } \\
\text { handling skills. }\end{array}$ & $\begin{array}{l}\text { 1) A federally regulated uniform open dating } \\
\text { system is necessary to make the practice more } \\
\text { consistent and consumer friendly; } \\
\text { 2) Open dating used in conjunction with TTIs } \\
\text { can inform consumers of the remaining shelf } \\
\text { life and proper temperature conditions } \\
\text { for storage. }\end{array}$ \\
\hline
\end{tabular}


Table A1. Cont.

\begin{tabular}{|c|c|c|c|c|c|c|c|}
\hline Study & Perspective & $\begin{array}{l}\text { Aim and Research } \\
\text { Question }\end{array}$ & $\begin{array}{l}\text { Research Methodology: } \\
\text { Qualitative or } \\
\text { Quantitative-Based }\end{array}$ & $\begin{array}{l}\text { Sample Size } \\
\text { and Region }\end{array}$ & Product Category & $\begin{array}{l}\text { Key Results Regarding the Role } \\
\text { that Date and Storage } \\
\text { Labeling Plays }\end{array}$ & Proposed Suggestions and Actions \\
\hline $\begin{array}{l}\text { Wansink and Wright, } \\
2006 \text { [64] }\end{array}$ & $\begin{array}{l}\text { Consumer food } \\
\text { safety }\end{array}$ & $\begin{array}{l}\text { How "Fresh if used by" } \\
\text { dating influences } \\
\text { consumers' acceptability } \\
\text { and taste perceptions. }\end{array}$ & $\begin{array}{l}\text { Taste experiment, } \\
\text { statistical analysis }\end{array}$ & $\begin{array}{l}36 \text { consumers in } \\
\text { the US }\end{array}$ & Yogurt & $\begin{array}{l}\text { Freshness dating (i.e., "Best if used } \\
\text { by") influences perceptions of } \\
\text { freshness and healthfulness, not } \\
\text { of safety. }\end{array}$ & $\begin{array}{l}\text { An important warning to companies is that as } \\
\text { a food approaches its "freshness date", there } \\
\text { may be more to lose than to gain from using } \\
\text { the "freshness dating." Efforts to use freshness } \\
\text { dating to connote safety or risk would } \\
\text { be misdirected. }\end{array}$ \\
\hline Terpstra et al., 2005 [65] & $\begin{array}{l}\text { Consumer food } \\
\text { edibility } \\
\text { assessment and } \\
\text { food safety }\end{array}$ & $\begin{array}{l}\text { To examine consumer } \\
\text { behavior and knowledge } \\
\text { concerning food storage } \\
\text { and disposal }\end{array}$ & $\begin{array}{l}\text { Interviews and } \\
\text { observations, qualitative } \\
\text { analysis }\end{array}$ & $\begin{array}{l}33 \text { consumers in } \\
\text { the Netherlands }\end{array}$ & $\begin{array}{l}\text { Meat, vegetables, } \\
\text { fruit juices, } \\
\text { leftovers, cheese, } \\
\text { dairy products }\end{array}$ & $\begin{array}{l}\text { 1) Different socio-demographical } \\
\text { groups deal with on-pack } \\
\text { instructions differently; } \\
\text { 2) Sensory assessments on product } \\
\text { features are useful as indications of } \\
\text { food quality, but they are not a } \\
\text { reliable indication of food safety. }\end{array}$ & $\begin{array}{l}\text { Consumer education about food safety, in } \\
\text { particular food storage and food handling, } \\
\text { is recommended. }\end{array}$ \\
\hline
\end{tabular}




\section{References}

1. European Commission Stop food Waste / Food Safety. Available online: https://ec.europa.eu/food/safety/ food_waste/stop_en (accessed on 20 January 2020).

2. Hebrok, M.; Boks, C. Household food waste: Drivers and potential intervention points for design-An extensive review. J. Clean. Prod. 2017, 151, 380-392. [CrossRef]

3. Schanes, K.; Dobernig, K.; Gözet, B. Food waste matters-A systematic review of household food waste practices and their policy implications. J. Clean. Prod. 2018, 182, 978-991. [CrossRef]

4. Wohner, B.; Pauer, E.; Heinrich, V.; Tacker, M. Packaging-Related Food Losses and Waste: An Overview of Drivers and Issues. Sustainability 2019, 11, 264. [CrossRef]

5. Wikström, F.; Williams, H.; Trischler, J.; Rowe, Z. The Importance of Packaging Functions for Food Waste of Different Products in Households. Sustainability 2019, 11, 2641. [CrossRef]

6. Wikström, F.; Williams, H.; Venkatesh, G. The influence of packaging attributes on recycling and food waste behaviour-An environmental comparison of two packaging alternatives. J. Clean. Prod. 2016, 137, 895-902. [CrossRef]

7. Wikström, F.; Verghese, K.; Auras, R.; Olsson, A.; Williams, H.; Wever, R.; Grönman, K.; Kvalvåg Pettersen, M.; Møller, H.; Soukka, R. Packaging Strategies That Save Food: A Research Agenda for 2030. J. Ind. Ecol. 2019, 23, 532-540. [CrossRef]

8. Toma, L.; Font, M.C.; Thompson, B. Impact of consumers' understanding of date labelling on food waste behaviour. Oper. Res. 2017. [CrossRef]

9. Milne, R. Arbiters of Waste: Date Labels, the Consumer and Knowing Good, Safe Food. Sociol. Rev. 2012, 60, 84-101. [CrossRef]

10. European Commission Food Information to Consumers-Legislation | Food Safety. Available online: https:/ec.europa.eu/food/safety/labelling_nutrition/labelling_legislation_en (accessed on 16 December 2019).

11. Himmelsbach, E.; Allen, A.; Mark, F. Study on the Impact of Food Information on Consumers' Decision Making; TSN European Behaviour Studies Consortium: Brussels, Belgium, 2014.

12. Lyndhurst, B. Consumer Insight: Date Labels and Storage Guidance; WRAP: Banbury, UK, 2011; ISBN 9781844054671.

13. European Commission. Flash Eurobarometer 425: Food Waste and Date Marking; Directorate-General for Communication (DG COMM): Brussels, Belgium, 2015.

14. Hebrok, M.; Heidenstrøm, N. Contextualising food waste prevention - Decisive moments within everyday practices. J. Clean. Prod. 2019, 210, 1435-1448. [CrossRef]

15. Aschemann-Witzel, J.; De Hooge, I.; Amani, P.; Bech-Larsen, T.; Oostindjer, M. Consumer-Related Food Waste: Causes and Potential for Action. Sustainability 2015, 7, 6457-6477. [CrossRef]

16. NSW EPA. Love Food, Hate Waste - NSW Food Waste Tracking Survey 2015-2016; New South Wales Government: Sydney, Australia, 2016.

17. Lyndhurst, B. Research into Consumer Behaviour in Relation to Food Dates and Portion Sizes; WRAP: Banbury, UK, 2008.

18. Soethoudt, J.M.; Van der Sluis, A.A.; Waarts, Y.; Tromp, S. Expiry Dates: A Waste of Time? Available online: https://ec.europa.eu/food/sites/food/files/safety/docs/fw_lib_report_2013_date-marking-and-foodwaste_nl-en.pdf (accessed on 30 January 2020).

19. Hall-Phillips, A.; Shah, P. Unclarity confusion and expiration date labels in the United States: A consumer perspective. J. Retail. Consum. Serv. 2017, 35, 118-126. [CrossRef]

20. Leib, E.B.; Gunders, D.; Ferro, J.; Nielsen, A.; Nosek, G.; Qu, J. The Dating Game: How Confusing Food Date Labels; National Resources Defense Council: New York, NY, USA, 2013.

21. Wikström, F.; Williams, H.; Verghese, K.; Clune, S. The influence of packaging attributes on consumer behaviour in food-packaging life cycle assessment studies - a neglected topic. J. Clean. Prod. 2014, 73, 100-108. [CrossRef]

22. Williams, H.; Wikström, F.; Otterbring, T.; Löfgren, M.; Gustafsson, A. Reasons for household food waste with special attention to packaging. J. Clean. Prod. 2012, 24, 141-148. [CrossRef]

23. Abeliotis, K.; Lasaridi, K.; Chroni, C. Food waste prevention in Athens, Greece: The effect of family characteristics. Waste Manag. Res. 2016, 34, 1210-1216. [CrossRef] [PubMed] 
24. Newsome, R.; Balestrini, C.G.; Baum, M.D.; Corby, J.; Fisher, W.; Goodburn, K.; Labuza, T.P.; Prince, G.; Thesmar, H.S.; Yiannas, F. Applications and Perceptions of Date Labeling of Food. Compr. Rev. Food Sci. Food Saf. 2014, 13, 745-769. [CrossRef]

25. Manzocco, L.; Alongi, M.; Sillani, S.; Nicoli, M.C. Technological and Consumer Strategies to Tackle Food Wasting. Food Eng. Rev. 2016, 8, 457-467. [CrossRef]

26. ReFED. A Roadmap to Reduce U.S. Food Waste by 20 Percent, 2016. Available online: https://www.refed. com/downloads/ReFED_Report_2016.pdf (accessed on 30 January 2020).

27. Labuza, T.P.; Szybist, L.M.; Peck, J. Perishable Refrigerated Products and Home Practices Survey. In Open Dating of Foods; Food \& Nutrition Press, Inc.: Trumbull, CT, USA, 2008; pp. 71-102.

28. Leib, E.B.; Schklair, A.; Greenberg, S. Consumer Perceptions of Date Labels: National Survey. Safety 2016, $23,19$.

29. Standardized Date Labeling: ReFED | Rethink Food Waste. Available online: https://www.refed.com/ solutions/standardized-date-labeling (accessed on 8 December 2019).

30. WRAP Food Date Labelling | WRAP UK. Available online: https://www.wrap.org.uk/food-date-labelling (accessed on 16 December 2019).

31. DEFRA. Guidance on the Application of Date Labels to Food, 2011. Available online: https://www.reading. ac.uk/foodlaw/label/dates-defra-guidance-2011.pdf (accessed on 8 December 2019).

32. Reisch, L.; Eberle, U.; Lorek, S. Sustainable food consumption: An overview of contemporary issues and policies. Sustain. Sci. Pract. Policy 2013, 9, 7-25. [CrossRef]

33. Woolley, E.; Garcia-Garcia, G.; Tseng, R.; Rahimifard, S. Manufacturing Resilience Via Inventory Management for Domestic Food Waste. Procedia CIRP 2016, 40, 372-377. [CrossRef]

34. Corradini, M.G. Shelf Life of Food Products: From Open Labeling to Real-Time Measurements. Annu. Rev. Food Sci. Technol. 2018, 9, 251-269. [CrossRef]

35. White, P.; Sharp, V.; Darnton, A.; Downing, P.; Strange, K.; Inman, A.; Garnett, T. Food Synthesis Review: A Report to the Department for Environment, Food and Rural Affairs; DEFRA: London, UK, 2009.

36. Leont'ev, A.N. The Problem of Activity in Psychology. Sov. Psychol. 1974, 13, 4-33. [CrossRef]

37. Leont'ev, A.N. Activity, Consciousness, and Personality; Prentice-Hall: Englewood Cliffs, NJ, USA, 1978; pp. 45-74. ISBN 9780130035332.

38. Kaptelinin, V.; Nardi, B.A.; Macaulay, C. Methods \& tools: The activity checklist: A tool for representing the "space" of context. Interactions 1999, 6, 27-39.

39. Yngfalk, C. The milk in the sink: Waste, date labelling and food disposal. In The Practice of the Meal: Food, Families and the Market Place; Routledge: Abingdon, UK, 2016; pp. 197-207. ISBN 9781315745558.

40. Glad, W. The design of energy efficient everyday practices. In eceee 2015 Summer Study on Energy Efficiency; European Council for an Energy Efficient Economy (ECEEE): Stockholm, Sweden, 2015; pp. 1611-1619.

41. Rexfelt, O.; Rosenblad, E. The progress of user requirements through a software development project. Int. J. Ind. Ergon. 2006, 36, 73-81. [CrossRef]

42. Selvefors, A.; Karlsson, I.C.M.; Rahe, U. Conflicts in Everyday Life: The Influence of Competing Goals on Domestic Energy Conservation. Sustainability 2015, 7, 5963-5980. [CrossRef]

43. Woll, A.; Bratteteig, T. Activity Theory as a Framework to Analyze Technology-Mediated Elderly Care. Mind Cult. Act. 2018, 25, 6-21. [CrossRef]

44. Chu, W.; Steenstra, P.; Glad, W.; Wever, R. Understanding context change: An activity theoretical analysis of exchange students' food consumption. In Proceedings of the NordDesign: Design in the Era of Digitalization, NordDesign 2018, Linköping, Sweden, 14-17 August 2018.

45. Engeström, Y. Learning by Expanding: An Activity-Theoretical Approach to Developmental Research, 2nd ed.; Cambridge University Press: Cambridge, UK, 2014; ISBN 9781139814744.

46. Verghese, K.; Lewis, H.; Lockrey, S.; Williams, H. Packaging's Role in Minimizing Food Loss and Waste Across the Supply Chain. Packag. Technol. Sci. 2015, 28, 603-620. [CrossRef]

47. Sanders, E.B.-N.; Stappers, P.J. Co-creation and the new landscapes of design. CoDesign 2008, 4, 5-18. [CrossRef]

48. Zimmerman, J.; Stolterman, E.; Forlizzi, J. An analysis and critique of research through design: Towards a formalization of a research approach. In Proceedings of the 8th ACM Conference on Designing Interactive Systems, DIS 2010, Aarhus, Denmark, 18-20 August 2010. 
49. Zimmerman, J.; Forlizzi, J.; Evenson, S. Research through design as a method for interaction design research in HCI. In Proceedings of the SIGCHI Conference on Human Factors in Computing Systems-CHI '07; ACM Press: New York, NY, USA, 2007; pp. 493-502.

50. Kitchenham, B.; Charters, S. Guidelines for performing Systematic Literature Reviews in Software Engineering; EBSE Technical Report Nr. EBSE-2007-01; Keele University: Newcastle, UK; Durham University: Durham, UK, 2007.

51. Kitchenham, B.; Brereton, O.P.; Budgen, D.; Turner, M.; Bailey, J.; Linkman, S. Systematic literature reviews in software engineering-A systematic literature review. Inf. Softw. Technol. 2009, 51, 7-15. [CrossRef]

52. Kitchenham, B. Procedures for Performing Systematic Literature Reviews; Keele University: Newcastle, UK; Durham University: Durham, UK, 2004.

53. Gustavsson, J.; Cederberg, C.; Sonesson, U.; van Otterdijk, R.; Meybeck, A. Global Food Losses and Food Waste: Extent, Causes and Prevention; Food and Agriculture Organisation of the United Nations: Rome, Italy, 2011.

54. Clemmensen, T.; Kaptelinin, V.; Nardi, B. Making HCI theory work: An analysis of the use of activity theory in HCI research. Behav. Inf. Technol. 2016, 35, 608-627. [CrossRef]

55. Wilson, N.L.; Rickard, B.J.; Saputo, R.; Ho, S.-T. Food waste: The role of date labels, package size, and product category. Food Qual. Preference 2017, 55, 35-44. [CrossRef]

56. Wilson, N.L.W.; Miao, R.; Weis, C. Seeing Is Not Believing: Perceptions of Date Labels over Food and Attributes. J. Food Prod. Mark. 2018, 24, 611-631. [CrossRef]

57. Thompson, B.; Toma, L.; Barnes, A.P.; Revoredo-Giha, C. The effect of date labels on willingness to consume dairy products: Implications for food waste reduction. Waste Manag. 2018, 78, 124-134. [CrossRef]

58. Roe, B.E.; Phinney, D.M.; Simons, C.T.; Badiger, A.S.; Bender, K.E.; Heldman, D.R. Discard intentions are lower for milk presented in containers without date labels. Food Qual. Preference 2018, 66, 13-18. [CrossRef]

59. Watson, M.; Meah, A. Food, Waste and Safety: Negotiating Conflicting Social Anxieties into the Practices of Domestic Provisioning. Soc. Rev. 2012, 60, 102-120. [CrossRef]

60. Aschemann-Witzel, J.; De Hooge, I.; Normann, A. Consumer-Related Food Waste: Role of Food Marketing and Retailers and Potential for Action. J. Int. Food Agribus. Mark. 2016, 28, 1-15. [CrossRef]

61. Dickinson, A.; Wills, W.; Meah, A.; Short, F. Food safety and older people: The Kitchen Life study. Br. J. Community Nurs. 2014, 19, 226-232. [CrossRef] [PubMed]

62. Lenhart, J.; Kendall, P.; Medeiros, L.; Doorn, J.; Schroeder, M.; Sofos, J. Consumer Assessment of Safety and Date Labeling Statements on Ready-to-Eat Meat and Poultry Products Designed to Minimize Risk of Listeriosis. J. Food Prot. 2008, 71, 70-76. [CrossRef] [PubMed]

63. Daelman, J.; Jacxsens, L.; Membré, J.-M.; Sas, B.; Devlieghere, F.; Uyttendaele, M. Behaviour of Belgian consumers, related to the consumption, storage and preparation of cooked chilled foods. Food Control 2013, 34, 681-690. [CrossRef]

64. Wansink, B.; Wright, A.O. "Best if Used By ... " How Freshness Dating Influences Food Acceptance. J. Food Sci. 2006, 71, S354-S357. [CrossRef]

65. Terpstra, M.; Steenbekkers, L.; De Maertelaere, N.; Nijhuis, S. Food storage and disposal: Consumer practices and knowledge. Br. Food J. 2005, 107, 526-533. [CrossRef]

66. Ceuppens, S.; Van Boxstael, S.; Westyn, A.; Devlieghere, F.; Uyttendaele, M. The heterogeneity in the type of shelf life label and storage instructions on refrigerated foods in supermarkets in Belgium and illustration of its impact on assessing the Listeria monocytogenes threshold level of $100 \mathrm{CFU} / \mathrm{g}$. Food Control 2016, 59, 377-385. [CrossRef]

67. Ransom, G. Considerations for establishing safety-based consume-by date labels for refrigerated ready-to-eat foods. J. Food Prot. 2005, 68.

68. Van Boxstael, S.; Devlieghere, F.; Berkvens, D.; Vermeulen, A.; Uyttendaele, M. Understanding and attitude regarding the shelf life labels and dates on pre-packed food products by Belgian consumers. Food Control 2014, 37, 85-92. [CrossRef]

69. Samotyja, U. Influence of shelf life labelling on the sensory acceptability of potato snacks. Br. Food J. 2015, 117, 222-233. [CrossRef]

70. European Commission. Preparatory Study on Food Waste Across Eu 27; Report for the European Commission [DG ENV—Directorate C]: Brussels, Belgium, 2010; ISBN 9789279221385. 
71. Sonigo, P.; Bain, J.; Tan, A.; Mudgal, S.; Murphy-Bokern, D.; Shields, L.; Aiking, H.; Verburg, P.H.; Erb, K.H.; Kastner, T. Assessment of Resource Efficiency in the Food Cycle; Final Report, Prepared for European Commission (DG ENV) in Collaboration with AEA, Dr Donal Murphy-Bokern, Institute of Social Ecology Vienna and Institute for Environmental Studies; European Commission: Brussels, Belgium, 2012.

72. Waarts, Y.; Eppink, M.; Oosterkamp, E.; Hiller, S.; Sluis, A.; van der Timmermans, T. Reducing Food Waste; Obstacles Experienced in Legislation and Regulations; LEI, Part of Wageningen UR: Wageningen, The Netherlands, 2011; ISBN 9789086155385.

73. Brook Lyndhurst and ESA. Helping Consumers Reduce Food Waste-A Retail Survey; WRAP: Banbury, UK, 2011.

74. Plumb, A.; Downing, P.; Parry, A. Consumer Attitudes to Food Waste and Food Packaging; Waste \& Resources Action Programme: Barbury, UK, 2013; ISBN 9781844054657.

75. Møller, H.; Hagtvedt, T.; Lødrup, N.; Andersen, J. Food Waste and Date Labelling: Issues Affecting the Durability; Nordic Council of Ministers: Copenhagen, Denmark, 2016; ISBN 9789289345569.

76. Aschemann-Witzel, J.; Ares, G.; Thøgersen, J.; Monteleone, E. A sense of sustainability?-How sensory consumer science can contribute to sustainable development of the food sector. Trends Food Sci. Technol. 2019, 90, 180-186. [CrossRef]

77. Ergönül, B. Consumer awareness and perception to food safety: A consumer analysis. Food Control 2013, 32, 461-471. [CrossRef]

78. Unklesbay, N.; Sneed, J.; Toma, R. College students' attitudes, practices, and knowledge of food safety. J. Food Prot. 1998, 61, 1175-1180. [CrossRef]

79. Brennan, M.; McCarthy, M.; Ritson, C. Why do consumers deviate from best microbiological food safety advice? An examination of 'high-risk' consumers on the island of Ireland. Appetite 2007, 49, 405-418. [CrossRef]

80. Nicoli, M.C. An introduction to food shelf life: Definitions, basic concepts, and regulatory aspects. In Shelf Life Assessment of Food; CRC Press: Boca Raton, FL, USA, 2012; ISBN 9781439846032.

81. Cox, J.; Downing, P. Food Behaviour Consumer Research: Quantitative Phase; Wrap: Barbury, UK, 2007.

82. European Commission "Best Before" and "Use By" Dates on Food Packaging. Available online: https: //ec.europa.eu/food/sites/food/files/safety/docs/fw_lib_best_before_en.pdf (accessed on 21 January 2020).

83. European Commission Infographic on Date Marking. Available online: https:/ec.europa.eu/food/sites/food/ files/safety/docs/fw_eu_actions_date_marking_infographic_en.pdf (accessed on 21 January 2020).

84. Kuswandi, B.; Wicaksono, Y.; Jayus, J.; Abdullah, A.; Heng, L.Y.; Ahmad, M. Smart packaging: Sensors for monitoring of food quality and safety. Sens. Instrum. Food Qual. Saf. 2011, 5, 137-146. [CrossRef]

85. Kumar, P.; Reinitz, H.; Simunovic, J.; Sandeep, K.; Franzon, P. Overview of RFID Technology and Its Applications in the Food Industry. J. Food Sci. 2009, 74, R101-R106. [CrossRef]

86. Collart, A.J.; Interis, M.G. Consumer Imperfect Information in the Market for Expired and Nearly Expired Foods and Implications for Reducing Food Waste. Sustainability 2018, 10, 3835. [CrossRef] 